SŁAWOMIR DRYJA

https://orcid.org/0000-0001-5359-3397

Uniwersytet Papieski Jana Pawła II w Krakowie

\title{
PODATEK AKCYZOWY OD PIWA W II RZECZYPOSPOLITEJ NA TLE OGÓLNEJ KONDYCJI PRZEMYSŁU PIWOWARSKIEGO
}

Zarys treści: $\mathrm{W}$ artykule przedstawiono problematykę podatku akcyzowego nakładanego na przemysł piwowarski w dwudziestoleciu międzywojennym. $\mathrm{W}$ szczególności wskazano na problemy wynikające $\mathrm{z}$ odmiennych systemów prawnych obowiazujących w poszczególnych dzielnicach zaborczych. Omówiono sposoby opodatkowania piwa ukształtowane w XIX w., w szczególności te obowiązujące w monarchii austro-węgierskiej, Rosji i Prusach. Wskazano podstawowe problemy przemysłu piwowarskiego w odrodzonym państwie polskim, w tym konieczność zrównania obciązeń podatkowych we wczesnych latach dwudziestych oraz w okresie szalejącej inflacji. Zwrócono uwagę na wysiłki środowiska piwowarskiego zmierzające do ustabilizowania produkcji i sprzedaży. Poddano ocenie uwarunkowania, jakim podlegało piwowarstwo w okresie dwudziestolecia międzywojennego.

The content outline: The paper discusses the issue of excise duty imposed on the beer brewing industry in the interwar period. It focuses in particular on the problems generated by incongruent legal systems in former partitions. The article opens with the discussion of various forms of taxation of beer production developed in the nineteenth century, especially those introduced in AustriaHungary, Russia, and Prussia. It indicates the greatest obstacles in the development of the beer brewing industry in reborn Poland, including the necessity to equalise tax burdens in the 1920s and in the period of raging inflation. It also mentions the efforts of the beer brewing sector aimed at stabilising production and sales and assesses the conditions faced by the beer brewing industry in the interwar period.

Słowa kluczowe: piwowarstwo, dwudziestolecie międzywojenne, podatek akcyzowy, system podatkowy, miary

Keywords: beer brewing, interwar period, excise duty, tax regime, measures 


\section{Zagadnienia wstępne}

Napoje alkoholowe od wieków stanowiły znakomity przedmiot opodatkowania. Daniny miały wieloraki charakter, obciążając zarówno producentów, jak również pośredników i bezpośrednich dystrybutorów. Nakładano je od produkcji, konsumpcji oraz handlu. W XIX w. obciążenie podatkami znacznie wzrosło, stały się one ważnym instrumentem polityki finansowej państwa. Znacząca rolę zaczął odgrywać podatek akcyzowy. Jest to podatek pośredni, nieposiadajaccy charakteru powszechnego. Nakłada się go na niektóre wyroby, najczęściej alkoholowe (piwo, wino, wódka), ale również inne produkty konsumpcyjne (tytoń, cukier, zapałki czy ropa naftowa lub inne źródła energii). Częstokroć wyroby akcyzowe obejmowano monopolem państwowym. Podatki akcyzowe stanowią zazwyczaj pokaźna część dochodów skarbowości państwa. Nie inaczej było w okresie II Rzeczypospolitej.

\section{Sposoby wymierzania i pobierania podatku od produkcji piwowarskiej}

W XIX w. ukształtowały się cztery zasadnicze sposoby pobierania podatku akcyzowego od produkcji piwowarskiej:

1) podatek od produktu gotowego - piwa przeznaczonego na sprzedaż;

2) podatek od półproduktu, czyli od brzeczki chmielonej, wymierzanej po ugotowaniu i ostudzeniu;

3) podatek od materiałów służących do produkcji piwowarskiej:

- liczony od surowców nieprzetworzonych (jęczmień lub inne zboża, chmiel),

- liczony od produktów przetworzonych (słód);

4) podatek od naczyń, w których produkowane jest piwo:

- liczony od objętości kotła warzelnego,

- liczony od objętości kadzi zaciernej.

Podatek od produktu gotowego pochodzi w prostej linii od systemów podatkowych rozwijających się i funkcjonujących w Europie od późnego średniowiecza. W Polsce takim podatkiem było czopowe. Jego pierwowzorem była ciza (cyza), ustanowiona po raz pierwszy w 1459 r. ${ }^{1}$ Podatek

${ }^{1}$ K. Boroda, Geografia gospodarcza Królestwa Polskiego w XVI wieku, Białystok 2016, s. 76. Najstarsze rejestry wpłat tego podatku zachowane sa z lat 1462-1465, z woj. poznańskiego i kaliskiego; A. Bieniaszewski, J. Latzke, Rejestr poboru cyzy z miast 
ten dotyczył piwa i miodu, jednak już w pierwszej połowie XVI w. został rozszerzony na wino i wódkę. Czopowe pobierano na podstawie uchwały sejmowej ${ }^{2}$, poczatkowo 1 gr od każdej beczki piwa przeznaczonego na sprzedaż. W 1578 r., za panowania Stefana Batorego, zmieniono sposób jego obliczania ${ }^{3}$. Jego wysokość określono na 2 denary od każdego grosza ustalonej ceny beczki gotowego produktu, wiążąc tym samym wysokość podatku z aktualnie obowiązująca cena piwa ${ }^{4}$. Z licznymi zmianami podatek ten przetrwał aż do upadku Rzeczypospolitej.

W XIX w. został on udoskonalony i zaczęto wybierać go z większą dokładnością. Upowszechniło się banderolowanie beczek i butelek z piwem. W Stanach Zjednoczonych rozlewane do naczyń transportowych piwo przepływało przez plombowane urządzenie pomiarowe ${ }^{5}$. Ten sposób opodatkowania uznawano za sprawiedliwy, jednak sprawiajacy sporo kłopotów z powodu nieustającej potrzeby kontroli państwowej. Problematyczne mogło też być ustalanie mocy piwa i związanej z tym stawki podatku. Stosowano tu dwojakie rozwiązania, obliczając moc piwa od ekstraktu brzeczki lub od zawartości alkoholu. Czesław Boczkowski zwracał uwagę, że „urzędnik państwowy musi być należycie wyszkolonym, aby nieuctwem swem nie wyrządzać szkody producentowi”. Preferował przy tym pomiar przeprowadzany w momencie przepompowywania piwa z naczyń fermentacyjnych do leżakowych ${ }^{6}$. W Europie system ten stosowano w Danii (licząc podatek od zawartości alkoholu), Rumunii (licząc

Wielkopolski $w$ latach 1462-1465, PH, t. 68, 1977, s. 541-553. W 1466 r. ustanowiono w Piotrkowie cizę przeznaczoną na pokrycie kosztów wojny z Zakonem Krzyżackim; J. Głuchowski, Konsumpcja jako przedmiot opodatkowania: casus akcyza, w: Finanse publiczne i prawo finansowe - realia i perspektywy zmian. Ksiega jubileuszowa dedykowana Profesorowi Eugeniuszowi Ruśkowskiemu, red. L. Etel, M. Tyniewicki, Białystok 2012 , s. 415.

${ }^{2}$ Podatek ten nie miał wiec charakteru stałego, a jedynie jednorazowy, a opłate wybierano przez rok od jego ogłoszenia; S. Dryja, Podatki $i$ opłaty pobierane od piwowarów krakowskich $w$ XVI i pierwszej połowie XVII wieku. Reforma czopowego z czasów panowania Stefana Batorego i jej wptyw na piwowarstwo krakowskie, RDSG, t. 78, 2017, s. 77.

3 VL, t. 2, Petersburg 1859, s. 985-990. Sposób taki obowiązywał też jednorazowo w 1544 r., po czym powrócono do starego systemu naliczania podatku; S. Dryja, Podatki $i$ optaty..., s. 77 .

${ }^{4}$ Podatek wynosił więc 1/9 wartości wyprodukowanego piwa (1 gr = 18 denarów).

${ }^{5}$ C. Boczkowski, Sposoby opodatkowania piwa. Odczyt wypowiedziany na posiedzeniu zjazdu właścicieli browarów, odbytem w Warszawie w dniu 17 i 18 stycznia 1919 roku, Warszawa 1919 (odb. z „Przeglądu Technicznego”), s. 5.

6 Tamże, s. 8. Stosowano wówczas otwarte naczynia fermentacyjne (kadzie). Po ustaniu fermentacji piwo przepompowywano do drewnianych naczyń leżakowych, zwanych kufami. 
podatek, jak w większości krajów europejskich, od ekstraktu brzeczki), Serbii, Bułgarii, Norwegii i Grecji. W krajach pozaeuropejskich upowszechnił się w Japonii, Australii, Nowej Zelandii i USA.

Podatek od półproduktu, czyli od brzeczki chmielonej, wymierzanej po ugotowaniu i ostudzeniu, oparty jest na pomiarze zawartości cukru, popularnie nazywany gęstością lub ekstraktem. Możliwość takiego obliczania zobowiązania podatkowego pojawiła się dzięki pracom prof. Carla Ballinga z Pragi. Udoskonalił on przyrząd nazywany cukromierzem, umożliwiajaccy określenie stężenia cukru w roztworze. Przyrząd ten wprowadzono do powszechnego użytkowania najpierw w cukrowniach, a następnie browarach. Stało się tak na mocy rozporządzenia z 19 XII 1852 r. ${ }^{7}$ Balling wprowadził opracowana przez siebie skalę, wedle której 1 stopień oznacza zawartość 1\% cukru (wagowo), czyli $10 \mathrm{~g}$ cukru na $1 \mathrm{~kg}$ roztworu. Należy jednak zaznaczyć, że wprowadzenie tego urządzenia w piwowarstwie ograniczała duża zawartość związków niecukrowych, mających znaczący wpływ na gęstość badanego roztworu. Powodowało to błąd odczytu, tym większy, im większa jest zawartość niecukrów w brzeczce ${ }^{8}$. Podany przez Ballinga przelicznik (dziś znany jako tzw. mały wzór) został przez niego wkrótce doprecyzowany (tzw. wielki wzór) ${ }^{9}$. W późniejszych latach skala ta była kilkakrotnie modyfikowana. Korektę wprowadził Adolf Brix, a następnie Fritz Plato. Należy jednak zaznaczyć, że skale Ballinga $\left({ }^{\circ} \mathrm{Blg}\right)$, Brixa $\left({ }^{\circ} \mathrm{Bx}\right)$ i Plato $\left({ }^{\circ} \mathrm{P}\right)$ różnią się od siebie dopiero na 5. i 6. miejscu po przecinku ${ }^{10}$. Wymierzenie podatku tym sposobem oznaczało konieczność określenia nie tylko zawartości cukru, ale i objętości brzeczki. Tę obliczało się na chłodnikach lub w specjalnie do tego przeznaczonych zbiornikach, za pomoca

${ }^{7}$ Rozporzadzenie ministra finansów z d. 19 Grudnia 1852, obowiazujace we wszystkich krajach koronnych z wyjatkiem Dalmacyi, w: Allgemeines Reichs-Gesetz-und Regierungsblatt für das Kaiserthum Osterreich = Powszechny Dziennik Praw Państwa i Rządu dla Cesarstwa Austryackiego, 1852, oddział 2, cz. 79, s. 1174-1180. Przepisy zaczęto stopniowo wprowadzać w życie od 1 II $1853 \mathrm{r}$.

${ }^{8}$ G. Basařova, Profesor Pražské techniky Carl Joseph Napoleon Balling (1805-1868), „Kvasný průmysl” 51, 2005, nr 4, s. 133.

${ }^{9}$ C.J.N. Balling, Die sacharometrische Bierprobe, Prag 1843; tenże, Die sacharometrische Bier -und Branntweinmeischprobe, Praha 1846; tenże, Die graphische und tabellarische Auflösung der sacharometrischen Bierprobe, Prag 1848; tenże, Anleitung zur Vornahme der sacharometrischen Bierprobe, Prag 1855; tenże, Anleitung zum Gebrauche des Sacharometers bei der Erzeugung und Prüfung der Bierwürzen zur Bestimmung ihres Extraktgehaltes, sowie zur vergleichsweisen Beurteilung der Qualität der Biere, Prag 1855.

${ }_{10}$ M.P. Manning. Understanding Specific Gravity and Extract, „Brewing Techniques” 1993, kopia w zbiorach autora. 
wzorów objętościowych. Powodowało to niezgodności pomiędzy urzędnikami skarbowymi a producentami, gdyż każdy milimetr różnicy w odczycie wysokości (po przemnożeniu przez powierzchnię chłodnika) dawał znaczące odchylenia od stanu faktycznego ${ }^{11}$. Podatek od półproduktu, jakim jest brzeczka, wprowadziły u siebie Austro-Węgry i Wielka Brytania (gdzie do oznaczania ciężaru właściwego brzeczki stosowano tzw. pignometry ${ }^{12}$ ), a następnie także Holandia, Włoch, Francja i Turcja. W późniejszym czasie Wielka Brytania częściowo zmodyfikowała swój system podatkowy, wprowadzając dodatkowo opodatkowanie od słodu (tzw. system mieszany) ${ }^{13}$.

Podatek od nieprzetworzonych materiałów służących do produkcji piwowarskiej, liczony od jęczmienia lub innych zbóż czy chmielu, nigdy nie zyskał większej popularności. Jęczmień niesłodowany podlegał opodatkowaniu w Anglii w latach 1697-1880. System został jednak zmieniony na rzecz opodatkowania od półproduktu (zob. wyżej). Przejściowo, od 1862 r., opodatkowano też chmiel. Podatek ten płacili producenci, pośrednio dotyczył jednak przemysłu piwowarskiego. Opodatkowanie jęczmienia niesłodowanego najdłużej utrzymało się w Norwegii. Jest to system skomplikowany i trudny do zastosowania w praktyce ${ }^{14}$. W celu łatwiejszego rozstrzygania sporów występujących pomiędzy urzędami a browarami rząd norweski odraczał płatność tego podatku nawet o 8 miesięcy $^{15}$.

Podatek od materiałów służących do produkcji piwowarskiej, liczony od słodu, niekiedy uważano za najpraktyczniejszy i najlepszy do zastosowania. Słód wymierzać można objętościowo lub wagowo, za pomoca urządzeń zatwierdzonych przez urząd podatkowy. System objętościowy stosowany był tradycyjnie w Bawarii i Finlandii. Podobnie jak w przypadku podatku od produktu gotowego, możemy się tu dopatrywać

${ }^{11} \mathrm{Z}$ technologicznego punktu widzenia przeprowadzanie pomiarów na tym etapie produkcji nie było najszczęśliwszym rozwiązaniem. Wyjałowiona i ochłodzona brzeczka powinna bowiem być jak najszybciej poddana procesowi fermentacji, by uniknać niebezpieczeństwa zakażenia.

12 Współczesny pignometr składa się z naczynia szklanego o określonej objętości oraz szlifowanego korka z zatopioną rurką kapilarna, która umożliwia łatwą obserwację poziomu cieczy umieszczonej w naczyniu. Pomiar polega na zważeniu masy cieczy po nalaniu do naczynia, zamknięciu (nadmiar wypłynie przez rurkę kapilarna) i doprowadzeniu do właściwej temperatury.

${ }^{13}$ C. Boczkowski, dz. cyt., s. 8-9.

${ }^{14} \mathrm{~W}$ trakcie procesu słodowania zboża (pszenica, jęczmień) zmieniaja swoją objętość i wagę; C.J. Lintner, Technologia browarnictwa, oprac. H. Lüers, tłum. P. Wojcieszak, Warszawa 1950, s. 27 n.

${ }^{15}$ C. Boczkowski, dz. cyt., s. 11. 
tradycji sięgającej jeszcze średniowiecza. Przypomnijmy, że materiały sypkie (zboża i słody) wymierzano wówczas objętościowo ${ }^{16}$. W XIX w. do wymierzania słodu stosowano specjalny samoczynny aparat. $\mathrm{W}$ większości krajów, które przyjęły pobór podatku tą metoda, zastosowanie miał pomiar wagowy. Podstawowym przyrządem w tym systemie jest waga, automatycznie oznaczająca na specjalnym liczniku ilość słodu przeznaczonego do ześrutowania ${ }^{17}$. System ten znalazł zastosowanie na terenie Niemiec, poza wspomniana Bawarią oraz Badenia, Alzacją i Lotaryngią. Użycie innego surowca niż słód jęczmienny nie sprawiało poborcom większych kłopotów w obliczeniu należnej stawki, gdyż stosowano specjalne tabele przeliczeniowe. Według nich $100 \mathrm{~kg}$ cukru trzcinowego lub słodu pszenicznego liczono odpowiednio jako 150 lub $80 \mathrm{~kg}$ słodu jęczmiennego. Podobny system wprowadzono w Szwecji, Grecji i Holandii (która przeszła nań z opodatkowania półproduktu). W 1902 r. taki sposób obliczania podatku przyjęto na terenie całego państwa rosyjskiego ${ }^{18}$.

Podatek od naczyń, w których produkowane jest piwo, polegał na objęciu kontrolą wymierzonych naczyń znajdujących się w warzelni. Wyznaczyć go można było od objętości kotła warzelnego, czyli naczynia służącego do gotowania brzeczki z chmielem. System ten stosowano we Francji, Badenii, Alzacji i Lotaryngii. Innym sposobem było opodatkowanie liczone od objętości kadzi zaciernej. System taki obowiązywał w Rosji do 1902 r. W Belgii stosowano system podwójny, wedle którego podatek płacono od wagi zużytego słodu lub - na żądanie wytwórcy - od pojemności kadzi zaciernej. W konstrukcji i tego podatku dostrzec można odległy ślad starszych systemów podatkowych. Czopowe odprowadzało się co prawda od każdej beczki wyprodukowanego produktu, jednak w celu ograniczenia nadużyć urządzenia standaryzowano, a ilość surowców użytych do produkcji określano w odrębnych przepisach. Wskazywały one tė̇ liczbę beczek, możliwą do pozyskania z jednej warki. Dobrym przykładem jest tu Obrachowanie kosztu waru piwa z 1593 r., regulujące system produkcji w browarach krakowskich. Wedle jego postanowień

${ }^{16}$ S. Dryja, Krakowskie miary piwowarskie $w$ XVI wieku, KHKM, t. 59, 2011, nr 1, s. $4 \mathrm{n}$.

17 Słód przeznaczony na warkę odmierzano porcjami, ustawiając wagę tak, by samoczynnie zakończyła pracę po odmierzeniu zakładanej ilości surowca. Wagę i śrutownik, jak również sztywne połączenie pomiędzy nimi, pieczętowano; Rady praktyczne dla piwowarów przy stosowaniu nowego sposobu opodatkowania piwa, oprac. K. Kujawski, Warszawa 1902, s. 45-47.

${ }^{18}$ Ustawę $\mathrm{O}$ pobieraniu akcyzy od piwowarstwa stosownie do wagi słodu zatwierdzono 10 VI 1900 r. Zniosła ona ustawę w brzmieniu z 1893 r. Nowe zasady zaczęły obowiązywać od początku 1902 r.; tamże, s. $1 \mathrm{n}$. 
piwo produkowano z wody, 12 ćwiertni „suchej pszenice” oraz 7 korców chmielu, w konsekwencji czego wielkość naczyń warzelnych była znormalizowana. Dozwolone było pozyskanie 28 beczek i 2 „na dolewkę" Opodatkowanie piwa od pojemności kadzi zaciernej miało wymierny wpływ na konstrukcję wszystkich naczyń warzelnych. Musiały one pozostawać w stałej proporcji objętościowej w stosunku do kadzi zaciernej ${ }^{20}$. Rzecz jasna miało to wpływ na technologię produkcji. Wyrabiano gęsty zacier, biorąc nawet trzyipółkrotnie mniej wody od przewidywanej ilości piwa $^{21}$. Wpływało to negatywnie na jakość końcowego produktu.

\section{Sposoby opodatkowania produkcji piwowarskiej w trzech dzielnicach zaborczych}

Na terenach ziem zaborczych obowiazywały trzy różne systemy opodatkowania produkcji piwowarskiej. Jedynie w dzielnicy austriackiej mówić możemy o długoletniej stabilizacji systemu podatkowego. W Rosji zasady obliczania podatku zmieniono w 1902 r., w Prusach zaś w 1918 r., niedługo przed odzyskaniem przez Polskę niepodległości.

Na terenie Prus, podobnie jak w znacznej części obszaru Niemiec (poza Badenia, Alzacją i Lotaryngia), obowiązywał podatek liczony od słodu użytego w produkcji. Jego struktura (wysokość, sposób naliczania, dodatkowe opłaty lokalne) nie była jednolita i różniła się nie tylko w poszczególnych krajach niemieckich, ale nawet w ich obrębie. Prawo z 15 VII 1909 r. uporządkowało przepisy akcyzowe, znosząc wcześniejsze stawki opodatkowania i wprowadzajac ujednolicone przepisy ${ }^{22}$. Nowe stawki miały charakter progresywny. Za pierwsze 25 ton przerobionego

19 S. Dryja, S. Sławiński, Mała encyklopedia piwowarska Krakowa i Kazimierza $w$ wieku XVI i pierwszej połowie wieku XVII. Studia z dziejów piwowarstwa Krakowa i Kazimierza z uwzględnieniem problematyki Kleparza i przedmieść, Kraków 2018, s. 292-298. Beczka miała pojemność 62 garnców, czyli 167,4 l.

${ }^{20}$ Przepisy pozwalały, by w warzelni znajdowały się następujące naczynia: kadź zacierna - od objętości której opłacano podatek, kadź filtracyjna - której objętość nie mogła przewyższać objętości kadzi zaciernej o więcej niż o 10\%, kocioł zacierny - o maksymalnej objętości do $2 / 3$ kadzi zaciernej i kocioł warzelny - o maksymalnej objętości 150\% kotła warzelnego; Rady praktyczne dla piwowarów..., s. 66-67.

${ }^{21}$ Ponieważ wyrobienie tak gęstego zacieru było trudne, na terenie państwa rosyjskiego modyfikowano kadzie zacierne w sposób niespotykany w innych częściach Europy.

${ }^{22}$ Oprócz stawek państwowych piwo obciążone było opłatami lokalnymi (gminnymi). Wprowadzane przepisy ograniczyły ich górną stawkę. Od piw słabych, o zawartości alkoholu do $1 \frac{3 \%}{4} \%$, stawka nie mogła przekraczać 30 fenigów od hektolitra, od piw mocniejszych - 65 fenigów; C. Boczkowski, dz. cyt., s. 9. 
słodu płacono 14 marek od kwintala ${ }^{23}$. Od kolejnych 125 ton płacono po 15 marek od kwintala, od następnych 150 ton po 16 marek od kwintala, a od dalszych 200 ton po 18 marek od kwintala. Przekroczenie pół tysiąca ton przerobionego słodu generowało opłatę w wysokości 20 marek za każdy kolejny kwintal ${ }^{24}$. System opłat podatkowych liczonych od słodu został częściowo naruszony ustawą z 24 I 1918 r. Została ona wymuszona trudna sytuacją ekonomiczna okresu wojennego i brakiem surowców do produkcji piwowarskiej. Zabroniono warzenia piw o ekstrakcie przekraczającym $3^{\circ} \mathrm{P}$ (Plato) ${ }^{25}$, co można uznać za drastyczne posunięcie. Napój o tak niskiej zawartości ekstraktu trudno wręcz uznać za piwo ${ }^{26}$. Stary system całkowicie zmieniła ustawa z 26 VII 1918 r. Od chwili wejścia jej w życia podatek liczono od hektolitra gotowego produktu (piwa). Nowe stawki również miały charakter progresywny ${ }^{27}$. Przepisy tej ustawy obowiązywały na ziemiach dawnego zaboru pruskiego po odzyskaniu przez Polskę niepodległości.

Na terenie Królestwa Polskiego, podobnie jak całej Rosji, wspólne prawo akcyzowe zostało zaprowadzone stosunkowo późno ${ }^{28}$. Zbiegło się to w czasie z likwidacją pozostałości odrębności Królestwa Polskiego i z reformami Aleksandra II modernizujacymi imperium. Ukaz o akcyzie państwowej w Królestwie Polskim ukazał się 7/19 VI 1866 r. Sprecyzowano w nim zasady poboru akcyzy od wyrobów alkoholowych, tytoniu, soli czy cukru. Podstawą obliczania podatku od browarów była pojemność kadzi zaciernej liczona w wiadrach (zob. tab. 1) ${ }^{29}$.

System ten ewaluował i ostateczny kształt przybrał w 1875 r. ${ }^{30}$ Postanowiono wówczas, że opłatę wylicza się od każdego wiadra objętości kadzi

${ }^{23}$ Miara podana w ustawie był „podwójny centnar (doppelzentner)”, 1 centnar niemiecki odpowiadał $50 \mathrm{~kg}$.

${ }^{24}$ Deutsches Reichsgesetzblatt, 1909, nr 39, poz. 3633, s. 695-704. W ustawie przewidziano możliwość wprowadzenia przepisów w Alzacji i Lotaryngii w dowolnym, późniejszym czasie.

${ }^{25}$ Deutsches Reichsgesetzblatt, 1918, nr 14, poz. 6230, s. 55-57.

${ }^{26}$ Współcześnie za piwo bezalkoholowe uznaje się takie, w którym zawartość alkoholu nie przekracza $0,5 \%$. Ekstrakt $3^{\circ} \mathrm{P}$ oznaczał piwo o zawartości alkoholu nieznacznie przekraczającej $1 \%$.

${ }^{27}$ Deutsches Reichsgesetzblatt, 1918, nr 98, poz. 6405, s. 863-885.

${ }^{28}$ Początki opodatkowania piwa sięgają 1861 r.; por. Encyklopedia rolnicza, t. 8: Nawożenie $i$ podlewanie drzew owocowych - Piwowarstwo i stodownictwo, Warszawa 1899, s. 698.

${ }^{29}$ K. Latawiec, Administracja akcyzowa na terenie Królestwa Polskiego $w$ latach 1866-1915, w: Dzieje biurokracji na ziemiach polskich, t. 1, red. A. Górak, I. Łuć, D. Magier, Radzyń Podlaski 2008, s. 267-269.

${ }^{30}$ Encyklopedia rolnicza..., t. 8, s. 698. 
Tabela 1. System miar objętości cieczy obowiązujący w Rosji od 1835 r. (w Królestwie Polskim od 1849 r.)

\begin{tabular}{|c|c|c|c|c|l|}
\hline Czarka & Sztof & Wiadro & Anker & Beczka & $\begin{array}{c}\text { Przeliczenie miar } \\
\text { na litry }\end{array}$ \\
\hline 1 & 10 & 100 & 300 & 4000 & 1 czarka $=0,01$ l \\
\hline & 1 & 10 & 30 & 400 & 1 sztof $=1,22991$ \\
\hline & & 1 & 3 & 40 & 1 wiadro $=12,299 \mathrm{l}$ \\
\hline & & & 1 & $131 / 3$ & 1 anker $=36,8971$ \\
\hline & & & & 1 & 1 beczka $=491,961$ \\
\hline
\end{tabular}

Źródło: oprac. na podstawie: Rady praktyczne dla piwowarów przy stosowaniu nowego sposobu opodatkowania piwa, oprac. K. Kujawski, Warszawa 1902, s. 158-161.

zaciernej, a proporcje innych naczyń (kadź filtracyjna, kocioł zacierny i kocioł warzelny) musiały pozostawać z nią w stałej zależności. Przyjęta stopa podatkowa wynosiła 12 kopiejek od wiadra ${ }^{31}$. W 1879 r. podniesiono ją do 20 kopiejek. Nie była to ostatnia podwyżka, w 1892 r. opłata wzrosła bowiem do 30 kopiejek. Przekładało się to na ok. 25 kopiejek opłaty od wiadra piwa handlowego. Wielokrotnie podnoszono, że opodatkowanie liczone od objętości kadzi zaciernej jest niejasne i nie do końca sprawiedliwe, a co więcej, krępuje technikę piwowarską i możliwość wprowadzania ulepszeń ${ }^{32}$. Wieloletnie starania piwowarów o zmianę tego stanu rzeczy w końcu się powiodły. W 1902 r. wprowadzono nowe zasady, za podstawę opodatkowania przyjmując ilość słodu zużytego na warkę ${ }^{33}$. Warto $\mathrm{w}$ tym miejscu wspomnieć o utworzonej w Rosji w 1893 r. Głównej Izbie Miar i Wag, której kierownikiem mianowany został Dymitr Mendelejew. Jeden z dwudziestu oddziałów Izby mieścił się w Warszawie. Rozpoczął on działalność 1 IX 1900 r., już po wprowadzeniu nowej ustawy o miarach i wagach. Dopuszczała ona możliwość stosowania systemu metrycznego, pozostawiając jednak jako obowiąujący system rosyjski ${ }^{34}$.

$\mathrm{Na}$ terenie Galicji dawne przepisy podatkowe zniesiono dopiero w 1829 r., wraz z wprowadzeniem na terenie całej monarchii powszechnego podatku konsumpcyjnego. Rzecz jasna nowy podatek obją też

31 Wedle J.L. Kaczkowskiego przekładało się to na akcyzę w wysokości 8 kopiejek od wiadra piwa typu bawarskiego i 5 kopiejek od wiadra piwa zwyczajnego; tenże, Piwowarstwo, „Gazeta Przemysłowo-Rzemieślnicza” 1875, s. 346, 357, 363.

${ }^{32}$ Encyklopedia rolnicza..., t. 8, s. 698-699.

${ }^{33}$ Ustawa z 13 I 1902 r., pełny tekst w: Rady praktyczne dla piwowarów..., s. 61-67; por. też uwagi w: C. Boczkowski, dz. cyt., s. 15.

34 A. Barański, Z.L. Warsza, Miary na ziemiach polskich $w$ dobie porozbiorowej, „Pomiary Automatyka Kontrola” 58, 2012, nr 12, s. 1137-1140. 
Tabela 2. System miar ciał sypkich (nasypnych) obowiąujacy w Rosji od 1835 r. (w Królestwie Polskim od 1849 r.)

\begin{tabular}{|c|c|r|r|r|l|}
\hline Zołotnik & Lut & Funt & Pud & Berkowiec & $\begin{array}{c}\text { Przeliczenie miar } \\
\text { na litry }\end{array}$ \\
\hline 1 & 3 & 96 & 3840 & 38400 & 1 zołotnik $=4,2558 \mathrm{~g}$ \\
\hline & 1 & 32 & 1280 & 12800 & 1 fut $=12,787 \mathrm{~g}$ \\
\hline & & 1 & 40 & 400 & 1 funt $=409,512 \mathrm{~g}$ \\
\hline & & & 1 & 10 & 1 pud $=16,38 \mathrm{~kg}$ \\
\hline & & & & & 1 berkowiec $=163,81 \mathrm{~kg}$ \\
\hline
\end{tabular}

Źródło: oprac. na podstawie: Rady praktyczne dla piwowarów przy stosowaniu nowego sposobu opodatkowania piwa, oprac. K. Kujawski, Warszawa 1902, s. 158-161.

wyroby piwowarskie ${ }^{35}$. Ustawa uchylała wcześniej obowiązujące opłaty (w Galicji były to tzw. kotłowe i szynkarskie), co wiązało się z przyznaniem adekwatnych odszkodowań. W Galicji i Bukowinie wysokość podatku ustalono na 20 krajcarów od wiadra piwa (gotowego produktu). $\mathrm{W}$ miastach zamkniętych pobierano dodatkową opłatę $\mathrm{w}$ wysokości 20 krajcarów od wiadra (zob. tab. 2 i 3$)^{36}$. Ten wydawałoby się prosty podatek miał wiele wad, z których podstawową był brak zróżnicowania pomiędzy gatunkami piw, w związku z czym lekkie jasne piwa obciażano na równi z mocnymi piwami ciemnymi. Zapewne $\mathrm{z}$ tego powodu rozporządzeniem z 19 XII $1852 \mathrm{r}$. wprowadzono znowelizowany podatek, któremu podlegał już nie produkt końcowy (czyli piwo), lecz półprodukt w postaci brzeczki ${ }^{37}$. Badanie brzeczki odbywało się na próbkach pobranych z chłodnika, w temperaturze $14^{\circ}$ Réaumura (17,5 Celsjusza). Podatek był wynikiem przemnożenia wskazania cukromierza i objętości (jednostką przeliczeniową było wiadro wiedeńskie), a stawkę podstawowa określono w wysokości 2,5 krajcara od tzw. wiadrostopnia, z zastrzeżeniem, „iż należytość nie będzie nigdy wymierzoną niżej kwoty wypadajacej od 12 stopni sacharometru, a obliczenie według pojedynczych stopni tylko od tej jętości ekstraktu miejsce mieć może, która 12 stopni przewyższa”. W rzeczywistości płacono więc pół guldena ${ }^{38}$ od każdego wiadra

${ }_{35}$ Należy jednak podkreślić, że prace zmierzające do ujednolicenia zasad poboru podatków prowadzono jeszcze w czasach panowania cesarzowej Marii Teresy (zm. 1770); A. Spyra, Browarnictwo Galicji doby autonomicznej, Kraków 1994, s. 64.

${ }^{36}$ Tamże.

${ }^{37}$ Wykorzystano tu przywołane wyżej (zob. przyp. 9) prace prof. Carla Ballinga z Pragi. Przepisy wprowadzano stopniowo, dając browarom czas na dostosowanie się do nowych regul.

${ }^{38}$ Do 1857 r. obowiązywał w Austrii system, w którym gulden dzielił się na 60 krajcarów (ten zaś na 4 fenigi lub 8 halerzy). 2 guldeny równały się 1 talarowi. 
wyrobionego piwa, doliczając po 2,5 krajcara za każdy stopień powyżej 12 stopni ekstraktu ${ }^{39}$. Równocześnie wprowadzono zakaz rozpuszczania brzeczki (poprzez dodanie wody) poniżej $11^{\circ} \mathrm{Blg}^{40}$. W $1857 \mathrm{r}$., w związku $\mathrm{z}$ reformą monetarną wprowadzono kolejną zmianę ${ }^{41}$. Podstawową stopę podatku określono na 0,36 złotych reńskich od brzeczki o mocy $9^{\circ} \mathrm{Blg}$. Za każde następne wiadro i stopień cukromierza doliczano po 0,4 złotych reńskich. Utrzymano dodatkowa opłatę od wiadra w wysokości 0,2 złotych reńskich w miastach zamkniętych ${ }^{42}$. W 1859 r. uchwalono specjalny „dodatek wojenny”, w związku z kosztownymi reformami systemu obrony państwa. Zwiększyło to realną stopę podatku o ok. 20\%. Kolejna reforma miała miejsce w 1869 r. i oznaczała dalsze zwiększenie zobowiązań. Wprowadzono jednolity podatek w wysokości 10 krajcarów od każdego wiadra i stopnia cukromierza (w miastach zamkniętych stopa podstawowa podatku wynosiła 42 krajcary $)^{43}$. W 1875 r. na terenie monarchii austro-węgierskiej zaprowadzono dziesiętny system metryczny. Wymagało to przeliczenia stopy podatku podstawowego. Stało się to pretekstem do kolejnej podwyżki. Po przeliczeniu stawka podatku wynosiła 16,7 krajcara (wraz z dodatkiem nadzwyczajnym) od hektolitra i każdego stopnia cukromierza. Zniesiono jednak dodatkowe opłaty w miastach zamkniętych ${ }^{44}$. Ostatnia zmiana miała miejsce w 1899 r., kiedy wprowadzono jednolitą opłatę w wysokości 33,4 halerzy ${ }^{45}$ od tzw. hektolitrostopnia (będacego iloczynem wskazania cukromierza i objętości). Dla browarów mniejszych wprowadzono upusty: do 2 tys. hektolitrów (hl)

${ }^{39}$ Wysokość podatku była zróżnicowana w różnych częściach monarchii. Dla Galicji i Lodomerii z Wielkim Księstwem Krakowskim i Bukowiną ustalono najniższą stawkę. Dla Czech wynosiła ona np. 31/4 krajcara.

${ }^{40}$ We współczesnej literaturze punkt ten mylnie interpretowano jako zakaz produkcji piw poniżej $11^{\circ} \mathrm{Blg}$ w ogóle. W rzeczywistości produkcja takich piw była jak najbardziej możliwa (np. browar Okocim produkował piwo o zawartości 10 stopni ekstraktu); por. A. Spyra, dz. cyt., s. 64; Rozporządzenie ministra finansów z 19 XII 1852 r., obowiąujące we wszystkich krajach koronnych z wyjątkiem Dalmacyi, „Allgemeines Reichs-Gesetz-und Regierungsblatt für das Kaiserthum Osterreich = Powszechny Dziennik Praw Państwa i Rządu dla Cesarstwa Austryackiego", 1852, oddział 2, cz. 79, s. 1174-1180.

${ }^{41} \mathrm{~W} 1857$ r. nastapiła zmiana w systemie monetarnym. Gulden (złoty reński) liczący dotąd 60 krajcarów zastapiony został guldenem dzielącym się na 100 krajcarów.

${ }^{42}$ Erlass des Finanzministeriums vom 28. August 1857, w: Reichsgesetzblatt für das Kaiserthum Osterreich, 1857, XXXIII, stück. 163, s. 468-471.

${ }^{43}$ Erlass des Finanzministeriums vom 25. April 1869, w: tamże, stück. 49, s. 175-176.

${ }^{44}$ Erlass vom 18. Mai 1875, w: Reichsgesetzblatt für die im Reichsrath vertretenen Königreiche und Länder, 1875, XXX, stück. 84, s. 203-209.

${ }^{45}$ Korona austro-węgierska została wprowadzona do obiegu w 1892 r., w związku z reformą systemu monetarnego. Guldeny wymieniano na korony w relacji 1:2; por. J. Szwagrzyk, Pieniadz na ziemiach polskich X-XX w., Wrocław 1990, s. 274. 
rocznej produkcji przysługiwał on w wysokości $15 \%$, do 5 tys. hl $-10 \%$, a przy produkcji do 15 tys. hl - 5\%. System nie miał jednak charakteru progresywnego, bowiem: „Przekroczenie tych najwyższych ilości jest jedynie wtedy dopuszczalne, gdy pierwej nastapi zwrot upustu, względnie różnicy zachodzącej między upustami”. Browary duże, o produkcji powyżej 15 tys. hl, płaciły stawkę podstawową już od pierwszego wyprodukowanego hektolitra ${ }^{46}$.

Tabela 3. System miar objętości cieczy obowiązujący w monarchii austro-węgierskiej do 1875 r.

\begin{tabular}{|c|c|c|l|}
\hline Zajdel & Miara & Wiadro & Przeliczenie miar na litry \\
\hline 1 & 4 & 160 & zajdel $=0,3561$ \\
\hline & 1 & 40 & miara $=1,4151$ \\
\hline & & 1 & wiadro wiedeńskie $=56,61$ \\
\hline
\end{tabular}

Źródło: oprac. na podstawie: J. Szymański, Nauki pomocnicze historii, wyd. 6, Warszawa 2005, s. 178.

Rozporządzenia podatkowe zawierały wiele przepisów i regulacji dotyczących sposobów prowadzenia kontroli skarbowej. Pod szczególnym nadzorem urzędów pozostawały chłodniki, na tym etapie produkcji bowiem brzeczka poddawana była ustawowym badaniom. Przepisy określały materiał budowlany, sposób wykonania i ustawienia tych urządzeń. Pod ścisłą kontrola pozostawały też kadzie fermentacyjne, w których ilość fermentującego piwa powinna zgadzać się z tą zapisaną na chłodniku. $\mathrm{Z}$ czasem wprowadzono zabezpieczenia $\mathrm{w}$ postaci plomb nakładanych na odpowiednie urządzenia. Obowiązkowe było wcześniejsze zgłoszenie warki i opłacenie podatku, po dopełnieniu czego browar otrzymywał tzw. boletę, czyli kwit pozwalający na przystapienie do pracy. W praktyce wnoszono rodzaj opłaty zryczałtowanej, w wysokości odpowiadającej kilku warkom, ostateczne rozliczenie pozostawiając na koniec miesiąca. Rozliczano się bowiem od ilości faktycznie wyprodukowanej brzeczki, ta zaś za każdym razem mogła być nieco inna. Różnica na niekorzyść browaru oznaczała konieczność dopłaty wraz z odsetkami, naliczanymi od ostatniej niepełnej przedpłaty.

${ }^{46}$ Rozporządzenie cesarskie z 17 VII 1899, zmieniające ustawy o podatkach pośrednich pozostających w ścisłym związku z produkcyą przemysłową, tudzież austriacko-węgierska taryfą cłowa, I część. Opodatkowanie piwa, w: Reichsgesetzblatt für die im Reichsrath vertretenen Königreiche und Länder = Dziennik ustaw państwa dla królestw i krajów w Radzie państwa reprezentowanych, 1899, cz. XLVIII, s. 225-230. 


\section{Przemysł piwowarski w przededniu Wielkiej Wojny i po odzyskaniu niepodległości}

Przemysł piwowarski w poszczególnych ziemiach zaborczych miał zróżnicowany potencjał. W tygodniku „Przemysł i Handel” w 1920 r. zamieszczono jego krótką charakterystykę: „Królestwo kongresowe, które liczyło przed wojną 194 browary, obecnie posiada 112. Małopolska przed wojna liczyła 83 browary, z czego obecnie jest czynnych około 50. Wielkopolska liczyła 53 niemieckie i 14 małych browarów polskich. Danych dotyczacych Ślaska i Prus brak nam dotychczas" ${ }^{\prime 7}$. Informacje te niewątpliwie oparto na dostępnych i wiarygodnych statystykach, możemy je jednak nieco uściślić.

Na terenie Królestwa Polskiego w 1910 r. funkcjonowało 195 browarów ${ }^{48}$, a w 1913 r. produkcję prowadziły 193 browary ${ }^{49}$. W Galicji w 1907 r. funkcjonowało 101 browarów, jednak w kolejnych latach ich liczba malała, w 1913 r. odnotowano już tylko 84 browary ${ }^{50}$. Wiele zakładów wyłączono z zamiarem chwilowego zawieszenia działalności, a wraz $\mathrm{z}$ poprawa koniunktury wiele $\mathrm{z}$ nich wznawiało produkcję ${ }^{51}$. Znacznie trudniejsze jest policzenie browarów funkcjonujących na terenie dawnego zaboru pruskiego. W 1913 r. w Prowincji Poznańskiej działalność prowadziło 109 browarów ${ }^{52}$. Pamiętać jednak musimy, że w granicach odrodzonej Polski znalazły się również browary z części Prus Książęcych i Królewskich oraz Ślaska Pruskiego ${ }^{53}$.

W okresie Wielkiej Wojny wiele zakładów zawiesiło produkcję, niektóre zaś - zlokalizowane w strefie działań wojennych - uległy zniszczeniu. Możemy ocenić, że potencjalnie na terytorium Polski znalazło się ok. 400 browarów zdolnych do podjęcia produkcji. W 1919 r. działalność wznowiły $282 \mathrm{z}$ nich ${ }^{54}$. Pierwsze wiarygodne dane statystyczne pochodza

47 „Przemysł i Handel” 1920, nr 6, s. 41.

${ }^{48}$ C. Boczkowski, dz. cyt., s. 6, tab. I.

${ }^{49}$ A. Spyra, dz. cyt., s. 85.

50 Tamże, s. 31.

${ }^{51}$ Dotyczyło to w szczególności małych browarów folwarcznych, często stosujących jeszcze fermentację górna. Browary takie unieruchamiano w ciepłych miesiącach lub podczas niesprzyjającej koniunktury.

${ }^{52}$ C. Boczkowski, dz. cyt., s. 6, tab. I.

${ }^{53}$ W 1913 r. na terenie Prus Książęcych funkcjonowało 101 browarów, na terenie Prus Królewskich było ich 69, a Śląska Pruskiego aż 462; tamże.

${ }^{54}$ Dane Związku Browarów i Słodowni w R.P.; „Przegląd Piwowarsko-Słodowniczy” 1, 1936, s. 40. Informację tę musimy traktować krytycznie, gdyż nie podano źródła jej pochodzenia. Liczbę browarów w 1914 r. oszacowano na 500, co świetle przytoczonych danych wydaje się wartością mocno zawyżona. 
dopiero z 1922 r. Odnotowano wówczas 243 browary czynne i 76 nieczynnych istniejących, a więc w sumie 319 (te drugie możemy traktować jako planujące wznowienie produkcji, co potwierdzono wykupem karty przemysłowej lub choćby przekazaniem danych statystycznych) ${ }^{55}$. Liczba ta mniej więcej zgadza się z danymi zawartymi w Księdze adresowej przemystu, handlu i finansów za 1922 r., w której odnotowano adresy 311 browarów ${ }^{56}$.

Pierwsze lata po odzyskaniu niepodległości okazały się trudne dla przemysłu piwowarskiego. W latach 1920-1923 zamknięto wiele browarów, co tłumaczy się brakiem surowców, kapitału obrotowego i niska chłonnościa rynku (spożycie piwa spadło do niespotykanie niskiego poziomu). W ocenie Zwiąku Piwowarów w Polsce, w 1919 r. otwarto zbyt wiele tego typu zakładów ${ }^{57}$. Spora część z nich nie miała żadnych szans na utrzymanie się na rynku, przerywając produkcję po kilku lub kilkunastu miesiaccach. Katastrofalne dla przemysłu piwowarskiego były lata 1923 i 1924 . Zamknięto wówczas 61 browarów. W 1925 r. ich liczba spadła poniżej 200 (zob. tab. 4) ( $^{58}$.

Tabela 4. Liczba browarów w Polsce w latach 1922-1928, z uwzględnieniem podziału na zakłady czynne (w ostatnim miesiącu roku) i nieczynne (w większości te, które zakończyły działalność przed końcem roku podatkowego)

\begin{tabular}{|c|c|c|c|}
\hline \multirow{2}{*}{ Rok } & \multicolumn{3}{|c|}{ Liczba browarów } \\
\cline { 2 - 4 } & czynnych & nieczynnych & ogółem \\
\hline 1922 & 243 & 76 & 319 \\
\hline 1923 & 247 & - & - \\
\hline 1924 & 221 & 61 & 282 \\
\hline 1925 & 196 & 74 & 270 \\
\hline 1926 & 183 & 85 & 268 \\
\hline 1927 & 182 & 65 & 247 \\
\hline 1928 & 188 & - & - \\
\hline
\end{tabular}

Źródło: oprac. na podstawie: „Rocznik Statystyki Rzeczypospolitej Polskiej” 1923 [1924], s. 51, tab. 12; 1925/1926 [1927], s. 156, tab. 19; 1927, s. 166, tab. 17; 1928, s. 159, tab. 18; 1928 [1930], s. 117, tab. 32. Brak danych za 1923 r., uzupełniono ja na podstawie informacji z „Biuletynu Związku Browarów i Słodowni w Polsce", choć są one w niektórych punktach rozbieżne z danymi z roczników statystycznych, co wynikać może z innej metodologii liczenia. Prawdopodobnie czynne browary liczono w skali całego roku, podczas gdy roczniki statystyczne podawały stan na koniec roku podatkowego (a więc faktycznie z grudnia).

55 „Rocznik Statystyki Rzeczypospolitej Polskiej” 1923 [1924], s. 51, tab. 12.

${ }^{56}$ Ksiega adresowa przemystu, handlu i finansów 1922, pod ogólnym kierownictwem komitetu redakcyjnego przy Ministerstwie Przemystu i Handlu, red. A.R. Sroka, Warszawa 1922, poz. 10628-10942.

57 „Przegląd Piwowarsko-Słodowniczy” 1, 1936, s. 40.

58 „Rocznik Statystyki Rzeczypospolitej Polskiej” 1925/1926 [1927], s. 156, tab. 19. 


\section{Sytuacja przemysłu piwowarskiego w latach 1918-1924 w świetle obowiązujących aktów prawnych}

Odradzająca się po okresie zaborów Rzeczpospolita odziedziczyła trzy systemy prawne, obowiązujące w poszczególnych dzielnicach zaborczych. Był to potężny problem, z którym musiało uporać się młode państwo. Sytuacja ta dotyczyła rzecz jasna również sposobu poboru akcyzy i podatków. Na ziemiach dawnego zaboru rosyjskiego podatek obliczano od ilości słodu zużytego w produkcji, w dawnym zaborze pruskim od ilości produktu gotowego (piwa) trafiającego na rynek, a w dawnym zaborze austriackim podstawą wymiaru był półsurowiec w postaci chmielonej brzeczki piwnej.

Pokłosiem okresu wojennego były niedobory surowcowe i wynikające stąd ograniczenia. Wprowadzono wówczas nie tylko limity w produkcji czy wspomniane wyżej zmniejszenie mocy (ekstraktywności) piwa (stąd pojęcie „piwo wojenne”), ale również reglamentację wyszynku. Przykładowo na terenie Austro-Węgier na mocy rozporządzenia z września 1916 r. ograniczono sprzedaż piwa w gospodach do trzech godzin w dni powszednie i sześciu w niedzielę i święta, przy dalszym obostrzeniu zabraniającym sprzedaży pojedynczemu klientowi więcej niż litra piwa (zarówno na miejscu, jak i na wynos) ${ }^{59}$. Limity te w oczywisty sposób rozciagały się na okres powojenny. Ministerstwo Aprowizacji odrodzonej Rzeczypospolitej zmuszone zostało do wprowadzenia ograniczeń „w browarach b. Kongresówki i Małopolski w roku gospodarczym 1920/21”. Przerób ziemiopłodów zmniejszono do 1/3 przerobu słodu w 1913 r., przy czym uściślono, że przy obliczaniu ilości jęczmienia zużytego do wyrobu słodu należy przyjąć wydajność „75 części suszonego słodu ze 100 części jęczmienia"60.

Sprzedaż napojów alkoholowych, w tym piwa, uregulowała ustawa z 23 IV 1920 r. O ograniczeniach w sprzedaży napojów alkoholowych. Dotyczyła ona trunków o zawartości powyżej 2,5\% alkoholu. Ustawa limitowała liczbę miejsc sprzedaży i wyszynku do jednego na 2500 mieszkańców z zastrzeżeniem, że miejsc wyszynkowych nie może być więcej niż połowa. Przewidziano możliwość całkowitego zakazu sprzedaży napojów alkoholowych na terenie gminy, pod warunkiem przeprowadzenia głosowania na wniosek 1/10 mieszkańców, którzy ukończyli 21. rok życia. Ustalono też minimalne odległości pomiędzy punktami sprzedaży a warsztatami fabrycznymi (zatrudniającymi powyżej 50 pracowników),

\footnotetext{
59 Dziennik Ustaw Państwa 1916, nr 140, poz. 299, s. 775.

${ }^{60}$ Dz. U. 1920 , nr 98 , poz. 657 , s. $1771-1772$.
} 
kościołami, domami modlitwy, szkołami, sądami, więzieniami, dworcami i stacjami kolejowymi ${ }^{61}$. W $1921 \mathrm{r}$. szeroko dyskutowano proponowana poprawkę zakładająca, by za napoje dopuszczone do wolnego obrotu uznać te o zawartości do 4\% alkoholu. Za wprowadzeniem tej poprawki optowali, rzecz jasna, przedstawiciele przemysłu piwowarskiego. Przeciwnicy wskazywali na nieuniknione - ich zdaniem - negatywne skutki takiej regulacji ${ }^{2}$. Poprawka ostatecznie przepadła. W 1922 r. jedynie uściślono niektóre przepisy oraz zmieniono tytuł ustawy tak, by objęła ona nie tylko sprzedaż, ale i spożycie napojów alkoholowych ${ }^{63}$.

W szerokim gronie fachowców toczono ożywiona dyskusję na temat formuły przyszłego opodatkowania produkcji piwowarskiej. Tematyka ta zdominowała zjazd właścicieli browarów w styczniu 1919 r., przygotowany z inicjatywy Stacji Doświadczalnej Zgromadzenia Piwowarów w Warszawie ${ }^{64}$. Obszerny wykład o sposobach opodatkowania piwa wygłosił wówczas inż. Czesław Boczkowski. Zjazd przyjął też wnioski skierowane do rządu. Czytamy w nich m.in.: „Jako najbardziej odpowiadający interesom Państwa i przemysłu winien być przyjęty za podstawe podatku akcyzowego od piwa system obliczania podatku za pośrednictwem wag automatycznych, oznaczajacych wagę materiału surowego - słodu", a więc wedle sposobu, który obowiązywał na terenie byłego zaboru rosyjskiego. Postulowano też udział piwowarów w opracowywaniu przyszłej ustawy, sugerując prostotę w obliczaniu podatku i jego umiarkowaną stopę. Proponowano też, by za piwo uznawać napój wyprodukowany ze słodu jęczmiennego, chmielu i drożdży. Użycie słodów z innych zbóż, podobnie jak cukru, byłoby możliwe jedynie za pozwoleniem ministra skarbu ${ }^{65}$.

Do czasu wprowadzenia nowej ustawy system opodatkowania opierał się na ustawodawstwie państw zaborczych ${ }^{66}$. Rzecz jasna stawki podatkowe obowiązujące na terenie krajów zaborczych były zróżnicowane,

${ }^{61}$ Dz. U. 1920 , nr 37, poz. 210, s. 531-534.

${ }^{62}$ Por. m.in. W. Sterling, 21/2\% czy 4\%?, druk ulotny, przedr. z „Kuriera Polskiego”, 13 VI 1923.

${ }^{63}$ Dz. U. 1922, nr 12, poz. 104, s. 209-210.

${ }^{64}$ Stacja Doświadczalna Zgromadzenia Piwowarów w Warszawie istniała od 1898 r. Jej kierownikiem w 1919 r. był inż. Czesław Boczkowski. Stacje doświadczalne, związane z przemysłem rolnym, powstawały w Królestwie Polskim od lat osiemdziesiątych XIX w.; Stacje doświadczalne w Królestwie Polskim, ich zadanie i urzadzenie, Warszawa 1904 (Prace Delegacji Doświadczalnej przy Sekcji Rolnej w Warszawie), s. 34.

${ }^{65}$ C. Boczkowski, dz. cyt., s. 21.

${ }^{66}$ W. Kochan, Wyktady na kursach przeszkolenia kontroli skarbowej przy warszawskiej Izbie Skarbowej, Warszawa 1938, s. 91. 
obciążając w nierównomierny sposób zakłady piwowarskie. Podstawa do ich wyrównania stała się ustawa z $10 \mathrm{~V} 1921 \mathrm{r}$. O regulowaniu podatków od spożycia, zużycia, względnie produkcji na obszarze Rzeczypospolitej Polskiej. Przewidywała ona zrównanie stawek podatków od spożycia na obszarze całego kraju, jak również możliwość uchylania jednych i rozszerzania na wszystkie dzielnice innych ustaw. Stawki opodatkowania poszczególnych towarów miały być proporcjonalnie zrównane z obowiązującymi w latach $1912-1914^{67}$. Dobrym przykładem zastosowania tej ustawy w praktyce jest rozporządzenie z 11 X 1922 r., w którym zapisano: „na obszar byłych dzielnic austriackiej i rosyjskiej rozciaga się moc obowiązująca postanowień par. 15 wydanej dla b. dzielnicy pruskiej [...], wedle którego rozporządzenia nie dopuszcza się do obrotu przypraw i wyciagów służących do wyrobu piwa, z wyjątkiem barwnika piwnego sporządzanego z cukru" ${ }^{\prime}$. Z punktu widzenia konsumentów był to krok w dobrym kierunku, eliminował bowiem z rynku surogaty, obniżające jakość produktu, a niekiedy wręcz szkodliwe dla zdrowia. Browary mogły jednak nadal we własnym zakresie stosować surowce zastępcze. Przykładowo browar w Żywcu wykorzystywał suszone buraki do produkcji słabego piwa jasnego aż do początków $1924 \mathrm{r}^{69}$

Równocześnie prowadzono prace nad nową ustawą o opodatkowaniu piwa. Jej przyjęcie opóźniła trudna sytuacja gospodarcza oraz postępująca inflacja. Spowodowało to odłożenie jej uchwalenia aż do połowy $1924 \mathrm{r}$.

Do czasu jej wprowadzenia stawki podatku należało wyliczać tak, by były one jak najbardziej zbliżone we wszystkich trzech dzielnicach. Było ta zadanie dość karkołomne, z uwagi na zróżnicowane systemy opodatkowania. W tabelach 5, 6 i 7 przedstawiono wysokość stawek obowiazujących $\mathrm{w}$ poszczególnych dzielnicach według rozporządzeń ministra skarbu z 30 V, 19 IX 1921 i 11 X 1922 r. W majowych rozporządzeniach pominięto jeszcze dzielnicę pruska, zaznaczając jedynie (w rozporządzeniu dotyczacym b. zaboru rosyjskiego): „Jak długo w b. zaborze niemieckim podatek spożywczy od piwa nie będzie podwyższony do 2 marek od litra piwa, sprowadzanie piwa z tego obszaru do obszaru b. zaboru rosyjskiego nastapić może jedynie na podstawie pozwolenia udzielonego przez władzę skarbową". Świadczy to o tym, że na terenie dawnego zaboru pruskiego obowiązywały opłaty niższe niż w innych częściach

${ }^{67}$ Dz. U. 1921, nr 41, poz. 248, s. 591.

${ }^{68}$ Dz. U. 1922, nr 92, poz. 851, s. 1577-1579.

${ }^{69}$ Archiwum Państwowe w Katowicach, Oddział w Bielsku-Białej, Dyrekcja Dóbr Żywieckich w Żywcu, sygn. 263, s. 13, 25, 31. Do czerwca 1923 r. było to piwo o ekstrakcie zaledwie $5^{\circ} \mathrm{Blg}$, następnie $9^{\circ} \mathrm{Blg}$. 
Tabela 5. Zasady naliczania podatku i jego wysokości w markach polskich na terenie byłego zaboru rosyjskiego w świetle kolejnych rozporządzeń z 1921 i 1922 r.

\begin{tabular}{|l|l|c|}
\hline $\begin{array}{c}\text { Data } \\
\text { rozporządzenia }\end{array}$ & \multicolumn{1}{|c|}{ Sposób naliczania podatku } & $\begin{array}{c}\text { Wysokość } \\
\text { podatku }\end{array}$ \\
\hline \multirow{3}{*}{30 V 1921} & do 2000 pudów słodu (wielkość browaru), od 1 puda & 400 \\
\cline { 2 - 3 } & pow. 2000 pudów słodu (wielkość browaru), od 1 puda & 480 \\
\hline \multirow{3}{*}{19 IX 1921} & do 2000 pudów słodu (wielkość browaru), od 1 puda & 1000 \\
\cline { 2 - 3 } & pow. 2000 pudów słodu (wielkość browaru), od 1 puda & 1200 \\
\hline \multirow{3}{*}{11 X 1922} & do 2000 pudów słodu (wielkość browaru), od 1 puda & 4000 \\
\cline { 2 - 3 } & pow. 2000 pudów słodu (wielkość browaru), od 1 puda & 4800 \\
\cline { 2 - 3 }
\end{tabular}

Źródło: oprac. na podstawie: Dz. U. 1921, nr 50, poz. 305, s. 876; Dz. U. 1921, nr 53, poz. 336, s. 926-927; Dz. U. 1921, nr 85, poz. 610 , s. $1538-1539$; Dz. U. 1922 , nr 92, poz. 851, s. 1577-1579.

Tabela 6. Zasady naliczania podatku i jego wysokości w markach polskich na terenie byłego zaboru austriackiego w świetle kolejnych rozporządzeń z 1921 i 1922 r.

\begin{tabular}{|c|c|c|}
\hline $\begin{array}{c}\text { Data } \\
\text { rozporządzenia }\end{array}$ & Sposób naliczania podatku & $\begin{array}{c}\text { Wysokość } \\
\text { podatku }\end{array}$ \\
\hline \multirow[b]{5}{*}{$30 \mathrm{~V} 1921$} & do $10000 \mathrm{hl}$, za każdy hektolitrostopień & 46 \\
\hline & do $30000 \mathrm{hl}$, za każdy hektolitrostopień & 47 \\
\hline & do 50000 hl, za każdy hektolitrostopień & 48 \\
\hline & do 70000 hl, za każdy hektolitrostopień & 49 \\
\hline & powyżej $70000 \mathrm{hl}$, za każdy hektolitrostopień & 50 \\
\hline \multirow[b]{5}{*}{19 IX 1921} & do 10000 hl, za każdy hektolitrostopień & 115 \\
\hline & do 30000 hl, za każdy hektolitrostopień & 117,5 \\
\hline & do 50000 hl, za każdy hektolitrostopień & 120 \\
\hline & do 70000 hl, za każdy hektolitrostopień & 122,5 \\
\hline & powyżej $70000 \mathrm{hl}$, za każdy hektolitrostopień & 125 \\
\hline \multirow[b]{5}{*}{11 X 1922} & do 10000 hl, za każdy hektolitrostopień & 460 \\
\hline & do 30000 hl, za każdy hektolitrostopień & 470 \\
\hline & do 50000 hl, za każdy hektolitrostopień & 480 \\
\hline & do 70000 hl, za każdy hektolitrostopień & 490 \\
\hline & powyżej $70000 \mathrm{hl}$, za każdy hektolitrostopień & 500 \\
\hline
\end{tabular}

Źródło: oprac. na podstawie: Dz. U. 1921, nr 50, poz. 306, s. 876-878; Dz. U. 1921, nr 53, poz. 337, s. 927-928; Dz. U. 1921 , nr 85 , poz. 611 , s. $1539-1540$; Dz. U. 1922 , nr 92, poz. 851 , s. 1577-1579.

kraju, produkcja była więc bardziej opłacalna. Wymuszało to konieczność utrzymywania wewnętrznej granicy celnej, przywóz takiego piwa do dawnej dzielnicy rosyjskiej wiązał się bowiem nie tylko z pozwoleniem 
Tabela 7. Zasady naliczania podatku i jego wysokość (w markach polskich) na terenie byłego zaboru pruskiego w świetle kolejnych rozporządzeń z lat 1921 i $1922^{70}$

\begin{tabular}{|c|c|c|c|c|}
\hline $\begin{array}{c}\text { Data } \\
\text { rozporządzenia }\end{array}$ & \multicolumn{4}{|c|}{ Sposób naliczania podatku / wysokość podatku } \\
\hline $30 \mathrm{~V} 1921$ & \multicolumn{4}{|c|}{ brak danych } \\
\hline \multirow[t]{5}{*}{19 IX 1922} & \multirow[t]{2}{*}{ od produkcji } & \multicolumn{3}{|c|}{$\begin{array}{l}\text { za każdy } 1 \text { hl piwa, w zależności od zawartości } \\
\text { ekstraktu }\end{array}$} \\
\hline & & do $8^{\circ} \mathrm{Blg}$ & od $8,1^{\circ}$ do $13^{\circ} \mathrm{Blg}$ & od $13,1^{\circ} \mathrm{Blg}$ \\
\hline & do $10000 \mathrm{hl}$ & 900 & 950 & 1000 \\
\hline & kolejne $20000 \mathrm{hl}$ & 1800 & 1900 & 2000 \\
\hline & pow. $30000 \mathrm{hl}$ & 3600 & 3800 & 4000 \\
\hline \multirow[t]{5}{*}{11 X 1923} & od produkcji & \multicolumn{3}{|c|}{$\begin{array}{l}\text { za każdy } 1 \text { hl piwa, w zależności od zawartości eks- } \\
\text { traktu }\end{array}$} \\
\hline & & do $8^{\circ} \mathrm{Blg}$ & od $8,1^{\circ}$ do $13^{\circ} \mathrm{Blg}$ & od $13,1^{\circ} \mathrm{Blg}$ \\
\hline & do $10000 \mathrm{hl}$ & 3600 & 5850 & $+50 \%$ za każde $4^{\circ}$ \\
\hline & kolejne $20000 \mathrm{hl}$ & 3800 & 6180 & $+50 \%$ za każde $4^{\circ}$ \\
\hline & pow. $30000 \mathrm{hl}$ & 4000 & 6500 & $+50 \%$ za każde $4^{\circ}$ \\
\hline
\end{tabular}

Źródło: oprac. na podstawie: Dz. U. 1921, nr 85, poz. 612, s. 1541; Dz. U. 1922, nr 92, poz. 851, s. 1577-1579.

władzy skarbowej, ale również z koniecznością uiszczenia dodatkowego opodatkowania i wniesienia wyrównawczej opłaty akcyzowej ${ }^{71}$.

Dopiero w trzech rozporządzeniach ogłoszonych 19 września $1921 \mathrm{r}$. wyznaczono stawki opodatkowania dla wszystkich dzielnic. Wydaje się, że zróżnicowanie przyjęte dla byłego zaboru pruskiego, zakładajace podwojenie stawki bazowej po przekroczeniu pewnego limitu produkcyjnego (powyżej 10 tys. hl) i dalsze podwojenie po przekroczeniu 30 tys. hl, było nadmierne. Preferowało małe browary, upośledzając te o największej produkcji. Dlatego w kolejnym rozporządzeniu, z $11 \mathrm{X}$ 1922 r., stawki te zdecydowanie spłaszczono ${ }^{72}$.

Lektura kolejnych rozporządzeń nie przynosi oczywiście odpowiedzi na pytanie, czy stawki podatkowe udało się wyrównać, a jeśli tak, to w jakim stopniu. Wydaje się to kwestią na tyle interesująca, że warto pokusić się o wykonanie odpowiednich symulacji.

${ }^{70} 50 \%$ doliczane za każde $4^{\circ}$ Blg powyżej stawki dla piwa mocnego liczono od stawki bazowej dla piwa słabego. Dopłata wynosiła więc 1800 marek.

${ }^{71}$ Dz. U. 1921, nr 50, poz. 306, s. 876-878; por. też Z. Landau, J. Tomaszewski, Zarys historii gospodarczej Polski 1918-1939, wyd. 3, Warszawa 1971, s. 67.

${ }^{72}$ Dz. U. 1921, nr 85, poz. 610, s. 1538-1539; Dz. U. 1921, nr 85, poz. 611, s. 1539-1540; Dz. U. 1921, nr 85, poz. 612, s. 1541. 
Znając systemy opodatkowania w poszczególnych częściach kraju, można bowiem wyliczyć realny wskaźnik obrazujący poziom obciążenia fiskalnego browarów w poszczególnych częściach kraju. Za punkt odniesienia wybrano system podatkowy obowiązujacy $\mathrm{w}$ dawnym zaborze austriackim (półprodukt w postaci brzeczki), gdyż to właśnie w odniesieniu do niego najprościej jest wyliczyć analogiczne wskaźniki z terenów dawnego zaboru rosyjskiego (słód zużyty do produkcji) oraz pruskiego (produkt gotowy). Świadomie zrezygnowano ze szczegółowego opisywania zasad wykonanych przeliczen, opartych na znajomości technologii piwowarskiej, ograniczając się do podstawowych uwag w przypisie ${ }^{73}$. Pod uwagę wzięto stawki podatkowego podane w rozporządzeniu z $11 \mathrm{X}$ 1922 r., z odpowiednio skorygowanymi (spłaszczonymi) stawkami dla byłego zaboru pruskiego ${ }^{74}$.

Jako podstawę obliczeń przyjęto piwo pełne o zawartości ekstraktu $12^{\circ} \mathrm{Blg}$, uznajac je za najbardziej reprezentatywne. Kontrolne obliczenia dla piw słabszych i mocniejszych potwierdziły zaobserwowane tendencje. Wyniki przedstawiono w tabeli 8. Wskaźnik podstawowy, przyjęty dla niewielkiego browaru o rocznej produkcji do 10 tys. hl, na terenie byłego zaboru austriackiego, określono na poziomie 1 .

Przeprowadzona analiza pokazuje, że pomimo zupełnie odmiennych sposobów opodatkowania w różnych częściach kraju udało się zrównoważyć stawkę pobieranego podatku. Była ona sprawiedliwa, w równomiernym stopniu obciążając browary z poszczególnych dzielnic zaborczych. W nieznacznym stopniu preferowała niewielkie browary z terenu byłego zaboru rosyjskiego (o szacunkowej produkcji do $1724 \mathrm{hl}$ ). W przypadku ziem byłego zaboru pruskiego w uprzywilejowanej sytuacji znajdowały się browary nowocześnie wyposażone, w których występowały niewielkie zaniki produkcyjne. W przestarzałych browarach, w których zaniki przekraczały $15 \%$, realne obciążenie fiskalne było zdecydowanie wyższe.

${ }^{73}$ Przeliczając stawki podatkowe obowiązujące w zaborze rosyjskim, wzięto pod uwage przeciętną wydajność słodu określoną na podstawie: Rady praktyczne dla piwowarów... (przyjęto wskaźnik 63,7\%). Następnie skorzystano z tablic dołączonych do pracy i odczytano normatywną ilość brzeczki uzyskiwaną z 1 pudu słodu. Po przeliczeniu okazało się, że $100 \mathrm{hl}$ piwa o ekstrakcie $12^{\circ}$ Blg uzyskiwano z 1,16 puda. To pozwoliło na odniesienie stawek w byłym zaborze rosyjskim do systemu austriackiego. Wbrew pozorom trudniejsze było przeliczenie stawek obowiązujących w dawnym zaborze pruskim. Za podstawę przyjęto tu tzw. zaniki (najogólniej chodzi o różnicę pomiędzy ilością wyprodukowanej brzeczki a ilością uzyskane piwa). Te moga wahać się w szerokim zakresie. Przyjęto stosunkowo niski poziom 13\%.

${ }^{74}$ Dz. U. 1921, nr 85, poz. 610, s. 1538-1539; Dz. U. 1921, nr 85, poz. 611, s. $1539-1540$; Dz. U. 1921, nr 85, poz. 612 , s. 1541. 
Tabela 8. Porównanie obciążenia akcyzą produkcji piwowarskiej na terenie trzech dzielnic zaborczych za pomocą ujednoliconych wskaźników przeliczeniowych ${ }^{75}$

\begin{tabular}{|l|c|c|c|}
\hline Wielkość produkcji & Były zabór austriacki & Były zabór rosyjski & Były zabór pruski \\
\hline do ok. $1724 \mathrm{hl}^{*}$ & 1 & 0,84 & 0,93 \\
\hline do $10000 \mathrm{hl}$ & $\mathbf{1}$ & 1,01 & 0,93 \\
\hline do $30000 \mathrm{hl}$ & 1,01 & 1,01 & 0,95 \\
\hline do $50000 \mathrm{hl}$ & 1,02 & 1,01 & 0,96 \\
\hline do $70000 \mathrm{hl}$ & 1,03 & 1,01 & 0,98 \\
\hline pow. $70000 \mathrm{hl}$ & $1,04^{* *}$ & 1,01 & $0,99^{* *}$ \\
\hline
\end{tabular}

Legenda: * - orientacyjna produkcja małego browaru, przerabiającego 2000 pudów; ** - dodatkowo 0,1 za każde następne $10000 \mathrm{hl}$.

Źródło: oprac. na podstawie danych zawartych w tab. 7, sposób wyliczenia zob. przyp. 73.

W 1923 r., z uwagi na nasilajacca się inflację, stawki nowelizowano ośmiokrotnie ${ }^{76}$. Stosując przyjęty uprzednio klucz przeliczeniowy, zachowano zrównoważoną stawkę podatkową. Zrównanie stawek podatkowych dla browarów z różnych części kraju, obliczanych wedle odmiennych systemów, uznać należy za niewątpliwy sukces skarbowości odradzającego się państwa polskiego.

Ze sposobu wyliczania podatku w poszczególnych dzielnicach zaborczych nie można wywnioskować, w jakim stopniu obciążał on produkcję piwowarska. Dane statystyczne pokazuja jedynie malejącą liczbę browarów przy niewielkim wzroście produkcji w pierwszych latach po odzyskaniu niepodległości (znaczniejszy wzrost nastapił w latach 1927-1928). Do tego spożycie piwa na głowę statystycznego mieszkańca należało wówczas do jednego z najniższych w Europie i rozkładało się nierównomiernie w różnych częściach kraju. W województwach wschodnich (wileńskie, nowogródzkie, poleskie i wołyńskie) przeciętny mieszkaniec konsumował niewiele ponad litr piwa rocznie. Zdecydowanie więcej wypijano go w Wielkopolsce i na Górnym Śląsku. Duże różnice występowały też pomiędzy mieszkańcami miast i wsi ${ }^{77}$.

${ }^{75}$ Stawka bazowa (równa 1) została przyjęta dla browaru w byłym zaborze austriackim, o produkcji do $10000 \mathrm{hl}$ rocznie, dla piwa $12 \mathrm{Blg}$.

${ }^{76}$ Dz. U. 1923 , nr 32, poz. 210, s. 342-343; Dz. U. 1923 , nr 66, poz. 516, s. 746; Dz. U. 1923 , nr 68, poz. 527, s. 768769 ; Dz. U. 1923 , nr 69 , poz. 543, s. 784-785; Dz. U. 1923, nr 87, poz. 680, s. 996-997; Dz. U. 1923, nr 88, poz. 696, s. 1022; Dz. U. 1923, nr 93, poz. 740, s. 1075-1076; Dz. U. 1923, nr 104, poz. 812, s. 1242-1243; Dz. U. 1923, nr 114, poz. 917, s. 1383-1384; Dz. U. 1923, nr 126, poz. 1024, s. 1523-1524; Dz. U. 1923, nr 132, poz. 1073 , s. 1721 .

77 Zestawienia statystyczne z drugiej połowy XIX w. i sprzed Wielkiej Wojny wykazują dużą zgodność z danymi z okresu międzywojennego. Możemy więc stwierdzić, 
Obciążenie fiskalne produkcji piwowarskiej możemy określić, analizując zachowany zbiór kalkulacji kosztów wyrobu piwa w browarze w Żywcu, w okresie pomiędzy 4 IX 1922 a 26 VI 1924 r. (zob. tab. 9). W sumie zachowało się 15 takich dokumentów. Wykonanie aż tylu kalkulacji w tak krótkim czasie wiązało się ze wzrostem cen, wynikającym z szybkiej dewaluacji marki polskiej. W drugiej połowie 1923 r. obliczenia przeprowadzano co 3-4 tygodnie, jednak już pod koniec października okres dwutygodniowy stał się niewystarczający. Dlatego też Związek Ochrony Browarów dla Małopolski podjał decyzję, że regulacja cen następować będzie co tydzień. Zarząd browaru zwrócił się do związku z prośbą o zwolnienie go z konieczności każdorazowego przedstawiania kalkulacji (jej wykonanie angażowało prace 2 kancelistów na niemal 2 dni), zamierzano bowiem przedstawiać nowe ceny w każdy piątek, tak by mogły obowiąywać od poniedziałku rano. Proces ich wyliczania powiązano z przedwojennym poziomem cen, odniesionym do kursu waluty amerykańskiej na giełdzie warszawskiej, wedle której cena 1 hektolitra piwa o ekstrakcie $12^{\circ}$ Blg wynosiła 5 dolarów ${ }^{78}$.

Tabela 9. Kalkulacja kosztów produkcji piwa w browarze żywieckim (w markach polskich) z 23 VI 1923 r., w rozbiciu na poszczególne pozycje

\begin{tabular}{|c|c|c|c|c|c|}
\hline \multirow{2}{*}{ Pozycja kosztorysu } & \multicolumn{5}{|c|}{ Rodzaj piwa } \\
\hline & leżak $9^{\circ}$ & zdrój $12^{0}$ & marcowe $12^{\circ}$ & porter $22^{\circ}$ & ale $22^{\circ}$ \\
\hline surowce & $11,41 / 28,54$ & $13,41 / 29,14$ & $14,15 / 27,75$ & $32,39 / 39,5$ & $36,46 / 41,42$ \\
\hline energia (węgiel) & $2,75 / 6,86$ & $3,30 / 7,17$ & $3,57 / 7$ & $5,22 / 6,38$ & $5,22 / 5,93$ \\
\hline amortyzacja beczek & $1,34 / 3,35$ & $1,58 / 3,43$ & $1,74 / 3,41$ & $2,38 / 2,9$ & $2,38 / 2,7$ \\
\hline płace & $6,86 / 17,15$ & $6,86 / 14,9$ & $6,86 / 13,45$ & $6,86 / 8,37$ & $6,86 / 7,8$ \\
\hline koszty ogólnozakładowe & $4,18 / 10,45$ & $4,24 / 9,27$ & $4,28 / 8,39$ & $4,44 / 5,41$ & $4,44 / 5,05$ \\
\hline zaniki $6 \%$ & $1,96 / 4,9$ & $2,25 / 4,89$ & $2,40 / 4,71$ & $3,97 / 4,84$ & $4,21 / 4,78$ \\
\hline podatek obrotowy & $1,12 / 2,8$ & $1,29 / 2,8$ & $1,44 / 2,82$ & $2,30 / 2,8$ & $2,46 / 2,8$ \\
\hline długie leżakowanie & - & - & - & $3,30 / 4,02$ & $3,51 / 3,99$ \\
\hline zarobek & $4,30 / 10,75$ & $4,96 / 10,78$ & $7,10 / 13,92$ & $6,27 / 7,65$ & $7,59 / 8,63$ \\
\hline podatek & $6,08 / 15,2$ & $8,11 / 17,62$ & $9,46 / 18,55$ & $14,87 / 18,13$ & $14,87 / 16,9$ \\
\hline Razem & $40 / 100$ & $46 / 100$ & $51 / 100$ & $82 / 100$ & $88 / 100$ \\
\hline
\end{tabular}

Źródło: oprac. na podstawie: Archiwum Państwowe w Katowicach, Oddział w Bielsku-Białej, Dyrekcja Dóbr Żywieckich, sygn. 263, s. 41.

że różnice w spożyciu wynikały z głębokich uwarunkowań społecznych i historycznych, i nie były wynikiem np. nieszczelności w poborze podatków.

${ }^{78}$ Archiwum Państwowe w Katowicach, Oddział w Bielsku-Białej, Dyrekcja Dóbr Żywieckich, sygn. 263, s. 81. 
W styczniu 1924 r. rząd polski wydał rozporządzenie ustanawiające nową walutę - złotego, którego emitentem został nowo powstały (28 kwietnia) Bank Polski. Obie waluty pozostały w obiegu do końca czerwca, a możliwość wymiany marek polskich na złote zachowano do $31 \mathrm{~V}$ 1925 r. Ponieważ 1 zł był równy frankowi szwajcarskiemu, kalkulację cen z 11 I 1924 r. w browarze żywieckim wykonano w odniesieniu do szwajcarskiej waluty. Dopiero następna kalkulacja, z 26 czerwca tego roku, została w pełni oparta na nowo wprowadzonej złotówce (zob. tab. 10).

Tabela 10. Kalkulacja kosztów produkcji piwa w browarze żywieckim (w markach polskich)

\begin{tabular}{|c|c|c|c|c|c|}
\hline \multirow{2}{*}{$\begin{array}{l}\text { Data rozpo- } \\
\text { rządzenia }\end{array}$} & \multirow{2}{*}{$\begin{array}{l}\text { Stawka za } \\
\text { hektolitro- } \\
\text { stopień }\end{array}$} & \multicolumn{4}{|c|}{ Rodzaj piwa } \\
\hline & & leżak $5^{\circ} / 9^{\circ}$ & zdrój $12^{0}$ & marcowe $12^{\circ}$ & porter $22^{\circ}$ \\
\hline 4 IX 1922 & 125 & 4,01 & 5,45 & 5,25 & 4,94 \\
\hline 5 II 1923 & 500 & 4,46 & 6,25 & 6,48 & 6,11 \\
\hline 14 III 1923 & 500 & 2,23 & 3,66 & 3,89 & 4,23 \\
\hline 16 VI 1923 & 3750 & 14,06 & 16,07 & 17,5 & 18,75 \\
\hline 16 VII 1923 & 7500 & 17,76 & 20 & 21,43 & 21,37 \\
\hline 3 VIII 1923 & 7500 & 11,25 & 12,5 & 13,46 & 13,75 \\
\hline 18 VIII 1923 & 7500 & 7,85 & 8,82 & 9,05 & 10,31 \\
\hline 10 IX 1923 & 20000 & 15 & 16,67 & 17,5 & 19,13 \\
\hline $12 \times 1923$ & 20000 & 5,45 & 6,86 & 7,37 & 5,5 \\
\hline $24 \times 1923$ & 50000 & 11,25 & 12,77 & 14 & 12,22 \\
\hline 14 XI 1923 & 50000 & 5,63 & 6,67 & 7 & 6,88 \\
\hline 24 XI 1923 & 150000 & 13,5 & 16,36 & 17,5 & 17,37 \\
\hline 15 XII 1923 & 300000 & 13,85 & 17,14 & 18,26 & 20,63 \\
\hline 11 I 1924 & $52 \mathrm{ctm}$ & 13,16 & 14,86 & 15,83 & 16,34 \\
\hline 26 VI 1924 & $67 \mathrm{gr}$ & 15,2 & 17,62 & 18,55 & 18,13 \\
\hline
\end{tabular}

Źródło: oprac. na podstawie: Archiwum Państwowe w Katowicach, Oddział w Bielsku-Białej, Dyrekcja Dóbr Żywieckich, sygn. 263, s. 1-91.

Analiza kalkulacji cen piwa ze schyłkowego okresu wzmożonej inflacji jaskrawo unaocznia problemy budżetu z efektywnościa ściagania podatków. Wraz z wprowadzeniem nowej taksy podatek stanowił od 15 do 19\% wszystkich kosztów produkcji. Ponieważ jednak kalkulacje sporządzano częściej, niż pojawiały się nowe rozporządzenia odnośnie do stawek podatku (2-3 kalkulacje na jedno rozporządzenie), realny udział podatku w kosztach produkcji malał, w skrajnym przypadku do poziomu 2,23-4,23\%. Dopiero kalkulacja sporządzona po ustabilizowaniu cen, z 26 VI 1924 r., 
pokazuje właściwą skalę obciążenia podatkowego ${ }^{79}$. W zależności od gatunku piwa wynosiła ona od 15,2 do 18,13\% (maksymalnie nie więcej niż 20\%) ogólnych kosztów produkcji. Z pewną ostrożnościa możemy uznać, że odpowiada to poziomowi obciążeń podatkowych browarów działających na terenie II RP od momentu wyrównania stawek podatkowych (19 IX $1921 \mathrm{r}$.) do wprowadzenia nowej ustawy podatkowej w 1924 r. Musimy też pamiętać, że inflacja była jednym z czynników sprzyjajacych odbudowie rolnictwa i produkcji rolnej. Redukowała ono bowiem obciążenia fiskalne i zmniejszała realną wartość długów oraz co wykazano w powyższej analizie - obciążeń fiskalnych ${ }^{80}$.

\section{Ustawa z 12 VI 1924 r. o opodatkowaniu piwa}

Wraz z wprowadzeniem ustawy walutowej możliwe stało się powrócenie do tematu nowej ustawy o opodatkowaniu piwa i ujednolicenia stawek podatkowych od produkcji piwowarskiej. Zasadniczo jej kształt powstał jeszcze w 1923 r., jednak postępująca dewaluacja marki polskiej uniemożliwiła wprowadzenie jej w życie. Nową ustawę uchwalono 12 VI 1924 r. (publikacja nastapiła 29 lipca) ${ }^{81}$, a szczegółowe przepisy wykonawcze zostały wydane 25 sierpnia (publikacja 15 października) ${ }^{82}$. Dało to browarom możliwość przystosowania się do nowych przepisów, które weszły w życie od 1 I $1925 \mathrm{r}^{83}$

Ustawodawca zadecydował o wprowadzeniu podatku liczonego od produktu gotowego, czyli piwa przeznaczonego na sprzedaż. Zbliżony system obowiązywał na ziemiach byłego zaboru pruskiego ${ }^{84}$. Stało to w sprzeczności ze stanowiskiem zjazdu właścicieli browarów z 1919 r., zwołanego

79 Stawka za hektolitrostopień wynosiła $0,67 \mathrm{zł}$, co odpowiadało (w przybliżeniu) 1200000 marek polskich (wedle przyjętego kursu wymiany, $1 \mathrm{zl}=1800000$ marek polskich). W rozporządzeniu Rady Ministrów z 20 XII 1923 r. stawkę bazową w byłym zaborze austriackim dla browarów wyrabiających 70 tys. hl piwa podniesiono na 600 tys. marek polskich. Przeliczenie pokazuje, że w krótkim czasie nastapiło dalsze podwojenie stawek; Dz. U. 1923, nr 132, poz. 1073, bpag.

80 Z. Landau, J. Tomaszewski, dz. cyt., s. 91.

${ }^{81}$ Dz. U. 1924, nr 65, poz. 635, s. 957-961.

82 Dz. U. 1924 , nr 90, poz. 850, s. $1324-1358$.

${ }^{83}$ W. Kochan, dz. cyt., s. 91.

${ }^{84}$ Można mówić wprost o przyjęciu zasad ustawodawstwa niemieckiego. Podobne rozwiązania zastosowano przy innych podatkach konsumpcyjnych, w tym od spirytusu, tytoniu, cukru, oleju skalnego, zapałek, drożdży, wina gronowego, owocowego i musujacego. Spirytus, tytoń i zapałki objęte zostały ponadto monopolem państwowym; tamże, s. 92 . 
z inicjatywy Stacji Doświadczalnej Zgromadzenia Piwowarów w Warszawie, preferującym obliczanie podatku od ilości słodu zużytego na warkę. Przyznać jednak trzeba, że nie zachowały się dokumenty potwierdzające, by piwowarzy z innych części kraju popierali to rozwiąanie ${ }^{85}$. Z perspektywy czasu stwierdzić można, że wybrano rozwiązanie nowocześniejsze, a zarazem prostsze do wprowadzenia. Nie wymagało ono zakupu i montażu stosunkowo drogich i skomplikowanych urządzeń (wagi miernicze). Podstawą był pomiar gęstości brzeczki (standardowo wykonywany przez wszystkie browary) i naczyń, „w których ma się oznaczać ilość brzeczki bezpośrednio po ugotowaniu jej z chmielem”. Problematyczna była ilość zaników, podatek odprowadzano bowiem od piwa w chwili wydania go z browaru, zgodnie z pojemnością naczyń cechowanych przez Urząd Miar i Wag. Wprowadzono trzy stawki podatkowe, w zależności od mocy produkowanego piwa (zob. tab. 11).

Tabela 11. Podatek akcyzowy liczony od hektolitra piwa (w zł) wedle ustawy z 1924 r.

\begin{tabular}{|l|c|c|c|}
\hline \multirow{2}{*}{ Wymiar podatku } & \multicolumn{3}{|c|}{ Rodzaj piwa } \\
\cline { 2 - 4 } & pełne & dubeltowe & mocne \\
\hline od pierwszych $2000 \mathrm{hl}$ & 6 & 9 & 12 \\
\hline od następnych $8000 \mathrm{hl}$ & 6,30 & 9,45 & 12,60 \\
\hline ponad $10000 \mathrm{hl}$ & 6,60 & 9,90 & 13,20 \\
\hline
\end{tabular}

Źródło: oprac. na podstawie: Dz. U. 1924, nr 65, poz. 635, s. 958.

Za piwo pełne uważano produkt o ekstrakcie od $9^{\circ}$ do $12,99^{\circ} \mathrm{Blg}$, za piwo dubeltowe te o ekstrakcie od $13^{\circ}$ do $19,99^{\circ} \mathrm{Blg}$, a granicę piwa mocnego ustalono na $20^{\circ} \mathrm{Blg}$. Warzenie piwa o ekstrakcie poniżej $9^{\circ} \mathrm{Blg}$ było zabronione, jednak na ich produkcję mógł wyrazić zgodę minister skarbu. Zdefiniowano piwa słabe jako powstające w wyniku górnej fermentacji i z domieszką do zacieru co najmniej $50 \%$ słodu pszennego ${ }^{86}$. Był to ukłon w kierunku producentów tradycyjnych piw grodziskich (wytwarzanych w Grodzisku Wielkopolskim), cenionych w dwudziestoleciu międzywojennym. W 1929 r. na mocy rozporządzenia Rady Ministrów wprowadzono ochronę nazwy regionalnej „piwo grodziskie”, zastrzeżoną dla wytwórców, „którzy produkują lub produkować będą piwo na obszarze miasta Grodzisk Wielkopolski" ${ }^{7}$.

Oprócz podatku konsumpcyjnego ustawa zatwierdziła również podatek od wyrobu piwa. Pobierany on był z góry i wynosił 40 zł od 1500 hl

\footnotetext{
${ }^{85}$ W zjeździe uczestniczyli głównie właściciele browarów z byłego zaboru rosyjskiego.

${ }^{86}$ Dz. U. 1924, nr 65, poz. 635, s. 957-961.

${ }^{87}$ Dz. U. 1929, nr 72, poz. 548, s. 1119.
} 
brzeczki goracej „w chwili ukończenia warki” i takiej samej opłaty za każde następne $1500 \mathrm{hl}^{88}$.

Nad prawidłowością obliczania podatku czuwała Izba Skarbowa. Merytoryczny poziom jej pracowników podnoszono w trakcie regularnie organizowanych kursów, wydawano też materiały szkoleniowe. Zwracano w nich uwagę na najczęściej występujące nieprawidłowości i nadużycia. Równocześnie oceniano, że: „Ustawa o opodatkowaniu piwa jest $\mathrm{w}$ stosunku do producenta b. liberalna, majaca na celu podniesienie przemysłu krajowego i jest obliczona na płatnika lojalnego, a więc zadanie Kon[troli] Sk[arbowej] na browarach wymaga specjalnych zabiegów ostrożności i przezorności, aby być na wysokości swego zadania" ${ }^{2}$.

W 1931 r. wprowadzono nową ustawę O opodatkowaniu piwa, w której zachowano większość dotychczasowych uregulowań. Podniesiono stawki podatku od piwa pełnego, które wynosiły odtąd: „od pierwszych $2.000 \mathrm{hl}$, wydanych do obrotu w ciagu roku obrachunkowego po $8,30 \mathrm{zł}$ od 1 hektolitra, od następnych 8.000 po 8,75 zł od 1 hektolitra, od dalszych ilości po 9,20 od 1 hektolitra". Utrzymano zasadę podwyższania podatku o połowę od piwa dubeltowego i podwojenia opłaty od piwa mocnego (zob. tab. 12). Zwolniono natomiast od podatku piwo wywożone za granicę lub na obszar Wolnego Miasta Gdańska ${ }^{90}$.

Tabela 12. Podatek akcyzowy liczony od hektolitra piwa (w zł) wedle ustawy z $1931 \mathrm{r}$.

\begin{tabular}{|l|c|c|c|}
\hline \multirow{2}{*}{ Wymiar podatku } & \multicolumn{3}{|c|}{ Rodzaj piwa } \\
\cline { 2 - 4 } & pelne & dubeltowe & mocne \\
\hline od pierwszych $2000 \mathrm{hl}$ & 8,30 & 12,45 & 16,60 \\
\hline od następnych $8000 \mathrm{hl}$ & 8,75 & 13,125 & 17,50 \\
\hline ponad $10000 \mathrm{hl}$ & 9,20 & 13,80 & 18,40 \\
\hline
\end{tabular}

Źródło: oprac. na podstawie: Dz. U. 1931, nr 99, poz. 762, s. 1611.

Rzecz jasna podatek akcyzowy nie był jedyną daniną obciążająca produkcję piwowarską. Choć wykracza to poza przyjęty zakres niniejszego opracowania, wspomnieć tu należy o podatku obrotowym. Browary i słodownie objęte zostały ustawą $\mathrm{O}$ państwowym podatku przemysłowym z 15 VII 1925 r. Ujednolicała ona ostatecznie system podatków dochodowych od przedsiębiorstw i osób fizycznych. Podatek przemysłowy

${ }^{88}$ Dz. U. 1924, nr 65, poz. 635, s. 957.

89 W. Kochan, dz. cyt., s. 118.

90 Dz. U. 1931, nr 99, poz. 762. W ustawie objęto też podatkiem wyrób „ekstraktów służących do wyrobu piwa domowym sposobem”, czego nie ujęto w poprzedniej ustawie. 
pobierano w dwóch formach: świadectw przemysłowych oraz podatku od obrotu. Wysokość tego drugiego ustalono na $2 \%$, przewidując jednak wiele zniżek i zwolnień. Browary zaliczono do VI grupy, rozdzielonej na sześć kategorii, w zależności od wielkości wyrobu gorącej brzeczki. Cena świadectw przemysłowych dla browarów była zróżnicowana, uzależniona od miejsca prowadzenia działalności ${ }^{91}$, w przedziale od 40 do $120 \mathrm{z}^{92}$. Ustawa była kilkakrotnie modyfikowana. W $1935 \mathrm{r}$. rozporządzeniem ministra skarbu wprowadzono „scalony podatek przemysłowy od obrotów piwem, napojami winnymi, wódkami gatunkowymi, octem, kwasem octowym i drożdżami”. Piwo objęto stawka 4\%, liczona od przychodów brutto ${ }^{93}$. Już w kolejnym roku stawkę tę podniesiono do $6,8 \%{ }^{94}$. Od 1 I 1939 r. zniesiono dawny podatek przemysłowy, zastępując go podatkiem obrotowym, opartym na zmienionej konstrukcji prawnej ${ }^{95}$. Ostatnia zmiana legislacyjna dotycząca bezpośrednio piwa została wprowadzona z $1939 \mathrm{r}$. Chodzi o rozporządzenie ministra skarbu „o poborze scalonego podatku obrotowego od sprzedaży piwa, napojów winnych, wódek gatunkowych, octu, kwasu octowego i drożdży". Wydano je w związku z wejściem w życie omówionej wyżej ustawy o podatku obrotowym. Utrzymano w niej stawkę $6,8 \%$, liczoną od obrotu ${ }^{96}$.

Faktyczne obciążenie fiskalne po wprowadzeniu ustawy znakomicie pokazuje kalkulacja kosztów produkcji 1 hektolitra piwa, obliczona w 1925 r. w browarze w Osieku. Sporządzono ja dla 50 warek piwa, o uśrednionej wielkości $40 \mathrm{hl}$. Odpowiadało to mniej więcej półrocznej produkcji browaru. Koszt wyprodukowania $1 \mathrm{hl}$ piwa pełnego wyliczono na $50 \mathrm{zt}^{97}$. Podatek akcyzowy stanowił więc $12 \%$ kosztów produkcji (podatek obrotowy 1,25\%). Przeciętna cena sprzedaży wynosiła 52-56 zł, zatem marża browaru ustalona została na poziomie od 4 do $12 \%{ }^{98}$. Nowa ustawa przyniosła więc wyraźne obniżenie obciążeń fiskalnych. W stosunkowo krótkim czasie rynek piwowarski osiagnął względna stabilizację. Skutki nowych rozwiązań legislacyjnych należy więc ocenić pozytywnie.

${ }^{91}$ Wedle załączonej tabeli obszar kraju podzielono na pięć kategorii.

${ }_{92}$ Dz. U. 1925 , nr 79, poz. 550, s. $1156-1178$.

${ }_{93}$ Dz. U. 1935, nr 31, poz. 230, s. 527-530.

${ }_{94}$ Dz. U. 1936, nr 13, poz. 124, s. 245-247.

${ }_{95}$ Dz. U. 1938, nr 34, poz. 292, s. 563-568.

${ }_{96}$ Dz. U. 1939 , nr 9, poz. 51, s. 245-247

97 W dużym browarze (typu Żywiec) koszty ogólne były niewątpliwie niższe, zatem realne obciążenie fiskalne było jeszcze mniejsze i kształtowało się zapewne ok. 10\% wszystkich kosztów.

${ }^{98}$ S. Dryja, Browar parowy w Osieku, Kraków 2017, s. 60. 


\section{Przemysł piwowarski do września 1939 r.}

Lata 1926-1929 to okres sprzyjającej koniunktury, dostrzegalnej m.in. w zwiększonych dochodach z rolnictwa i szybkim wzroście produkcji przemysłowej. Były to również lata korzystne dla przemysłu piwowarskiego.

Po krótkiej stabilizacji w 1925 r. (działalność zakończył tylko jeden browar) w kolejnym roku zamknięto 35 zakładów, co tłumaczono faktem, „iż mogły istnieć (one) tylko w niezdrowej atmosferze inflacyjnej”99. W ciagu następnych 5 lat obserwujemy niespotykaną wcześniej stabilizację. W 1928 r. liczba browarów nawet nieznacznie wzrosła, choć bilans pięciolecia zamkną się ubytkiem trzech browarów.

Tabela 13. Roczna produkcja piwa (w hektolitrach) i słodu (w tonach) w Polsce w latach 1922-1928

\begin{tabular}{|c|c|c|}
\hline Rok & Roczna produkcja piwa & Roczna produkcja słodu \\
\hline 1922 & 1840110 & 28969 \\
\hline 1923 & brak danych & brak danych \\
\hline 1924 & 1641350 & 29086 \\
\hline 1925 & 1650920 & 31619 \\
\hline 1926 & 1689850 & 32315 \\
\hline 1927 & 2097110 & 40279 \\
\hline 1928 & 2510500 & 50106 \\
\hline
\end{tabular}

Źródło: oprac. na podstawie: „Rocznik Statystyki Rzeczypospolitej Polskiej” 1923 [1924], s. 51, tab. 12; 1925/1926 [1927], s. 156 , tab. 19; 1927, s. 166, tab. 17; 1928, s. 159 , tab. $18 ; 1928$ [1930], s. 117 , tab. 32 .

W tym okresie nastapił znaczacy wzrost produkcji i konsumpcji piwa (zob. tab. 13). W $1927 \mathrm{r}$. jego produkcja przekroczyła $2 \mathrm{mln}$ hl, rekordowy okazał się zaś rok 1929. Załamanie przyszło wraz z wielkim kryzysem ekonomicznym. Pomimo gwałtownego spadku produkcji większości browarów udało utrzymać się na rynku. W pięcioleciu 1930-1934 działalność zakończyło jedynie 15. Powszechnie przyjmuje się, że przesilenie kryzysu przemysłowego zaczęło następować w 1933 r., a jego kres datuje się na 1935 r. Kryzys w przemyśle piwowarskim był bardziej dotkliwy i miał bardziej dalekosiężne skutki - wyraźne ożywienie nastapiło dopiero w 1937 r. W tym czasie liczba browarów nadal spadała, choć nie miało to już skali porównywalnej z pierwszymi latami

99 „Przegląd Piwowarsko-Słodowniczy” 1, 1936, s. 40. 
powojennymi. W 1939 r. było ich już tylko $137^{100}$. Przy zauważalnym wzroście produkcji oznaczało to zdecydowanie wyższa produktywność przeciętnego zakładu. W rzeczywistości jednak na wzroście produkcji korzystały największe browary. Zakłady małe i średnie z trudem utrzymywały wcześniejszy poziom produkcji (zob. tab. 14).

Tabela 14. Poziom rocznej produkcji piwa w Polsce w latach 1929-1937

\begin{tabular}{|c|c|}
\hline Rok & Produkcja piwa (w tys. hektolitrów) \\
\hline 1929 & 2786 \\
\hline 1930 & 2516 \\
\hline 1931 & 1928 \\
\hline 1932 & 1400 \\
\hline 1933 & 1058 \\
\hline 1934 & 1172 \\
\hline 1935 & 1065 \\
\hline 1936 & 1179 \\
\hline 1937 & 1317 \\
\hline
\end{tabular}

Źródło: oprac. na podstawie: „Mały Rocznik Statystyczny” 1932 , s. $41 ; 1933$, s. $42 ; 1934$, s. $56 ; 1935$, s. $77 ; 1936$, s. 122 ; 1938 , s. 127.

W obliczu światowego kryzysu i spadku produkcji piwowarskiej zrzeszenia właścicielskie próbowały podejmować działania zaradcze. W $1930 \mathrm{r}$. w Centralnym Związku Przemysłu Piwowarskiego i Słodowniczego opracowano projekt powołania Biura Kontroli Produkcji i Handlu Piwem. Jego podstawowym celem było wprowadzenie dobrowolnych kontyngentów, realizujących naczelne hasło organizacji: „Każdemu browarowi małemu czy dużemu, nasza organizacja musi dać ubezpieczenie produkcji, ta jest pewność, że swoją produkcję w określonej wysokości sprzeda po określonej cenie, że w razie spadku spożycia nie będzie skrzywdzony przez browary konkurujące i wreszcie, że w przypadku, gdy spożycie będzie wzrastać, udział jego w produkcji będzie również wzrastać w stosunku, odpowiadającym jego niewyzyskanej zdolności produkcyjnej”101.

${ }^{100} \mathrm{Na}$ przełomie 1938 i 1939 r. zamknięto browary w Nisku, Sławatyczach, Jatutowie oraz łódzki browar Karola Anstadta. Do statystyk zaliczono browar w Karwinie na Śląsku Zaolziańskim; „Przegląd Piwowarsko-Słodowniczy” 1, 1939, s. 21.

101 Projekt Biura Kontroli Produkcji i Handlu Piwem, przy Centralnym Zwiazku Przemystu Piwowarskiego i Stodowniczego w Warszawie, Warszawa 1930, s. 4. 
Inicjatywa wyszła z kręgów właścicieli dużych browarów i choć wydawała się korzystna dla zakładów małych, nie spotkała się z należytym zainteresowaniem większości środowiska. Dlatego też w 1932 r. związek opracował projekt ustawy O uregulowaniu stosunków w przemyśle piwowarskim. Postulowano w nim, by na wniosek browarów, reprezentujących co najmniej połowę produkcji, minister przemysłu i handlu był uprawniony do powołania przymusowej organizacji przemysłu piwowarskiego, upoważnionej do kontyngentowania sprzedaży piwa, wedle zasad przedstawionych we wcześniejszym projekcie ${ }^{102}$. Pomimo starań, pomysłów tych nie udało się wprowadzić w życie.

W 1937 r. rozpatrywano nowelizację ustawy O opodatkowaniu piwa pod kątem możliwości dokonywania zmian w opłatach akcyzowych poprzez rozporządzenia ministra skarbu (dotąd regulowanych ustawowo). Wniosek rządowy, po akceptacji komisji sejmowej, był rozpatrywany przez Komisję Skarbową Senatu. Projekt ustawy referował senator Stefan Rydel. Po dyskusji skorygowano go w tym duchu, że nowela upoważniała ministra do obniżania stawek akcyzowych, a nie do wprowadzania zmian. Było to zgodne ze stanowiskiem Związku Browarów i Słodowni RP, chroniło bowiem producentów piwa przed niespodziewanymi zwyżkami podatku akcyzowego ${ }^{103}$. W uzasadnieniu rządowego projektu ustawy czytamy: „Spożycie piwa w kraju doznało w ostatnich latach głębokiego spadku pod wpływem kryzysu gospodarczego. Dla przyspieszenia odbudowy tego produktu w kraju niezbędne będzie prawdopodobnie zastosowanie szeregu środków tak na odcinku produkcji, jak i handlu piwem, nie wyłączając również rewizji cen piwa. Ażeby umożliwić władzy rządowej wsparcie [...] co do ewentualnej obniżki cen piwa należałoby dać możność wprowadzenia w drodze rozporządzeń i zmian wysokości podatku od piwa"104. Implementację poprawki odłożono do marca 1938 r., do artykułu 3 ustawy dodano wówczas nowy ustęp mówiący, że: „Minister Skarbu może zniżać w drodze rozporządzeń stawki podatku, określone w ust. (1) i (2)"105. Był to wyraźny ukłon w stronę środowiska piwowarskiego - stawki opodatkowania można było odtąd zmieniać rozporządzeniem (o co zabiegało ministerstwo), jednak jedynie w dół (na co naciskało lobby browarnicze). Podwyższenie stawek nadal wymagało zmiany ustawowej.

102 Projekt ustawy o uregulowaniu stosunków w przemyśle piwowarskim, oprac. Centralny Związek Przemysłu Piwowarskiego i Słodowniczego, Warszawa 1932.

103 „Przegląd Piwowarsko-Słodowniczy” 2, 1938, s. 45.

104 Rządowy projekt ustawy, druk nr 556 (tłoczony z polecenia marszałka Sejmu), bpag.

${ }^{105}$ Dz. U. 1938, nr 18, poz. 136. 


\section{Podsumowanie}

Dzieje przemysłu piwowarskiego jak w soczewce pokazują problemy, z którymi musiała zmierzyć się niepodległa Rzeczpospolita. W każdej z dzielnic zaborczych obowiazywał inny system wymierzania i poboru podatku od produkcji piwowarskiej, obciążający ją w nierównym stopniu. Różny był też potencjał, wyrażony w rocznym spożyciu piwa na głowę przeciętnego mieszkańca. Działania wojenne spowodowały zniszczenia i dewastacje wielu browarów, szczególnie we wschodniej części kraju. Ograniczenia surowcowe, wprowadzone w niedługim czasie po rozpoczęciu działań zbrojnych, doprowadziły do ograniczenia produkcji i zamknięcia wielu zakładów. Drastycznie obniżono maksymalny poziom ekstraktu brzeczki piwnej, w związku z czym „piwo wojenne” w niewielkim stopniu przypominało ten trunek.

W stosunkowo krótkim czasie udało się uporządkować system dystrybucji surowców. Zachowując systemy podatkowe obowiąujące na terenach poszczególnych ziem zaborczych, zrównano realny poziom odprowadzanych podatków. Zniesiono dzięki temu wewnętrzne granice celne. Niestety, trudności lat powojennych spowodowały, że wiele browarów nie wznowiło już produkcji, a liczba czynnych zakładów kurczyła się z roku na rok. Uchwalenie nowego, spójnego systemu podatkowego opóźniło się z powodu narastającej inflacji. Dopiero wprowadzenie nowej waluty pozwoliło uporządkować i ten sektor gospodarki. Nowe rozwiazania prawne bez wattpienia przyczyniły się do ustabilizowania rynku piwowarskiego. Okres pomyślnego rozwoju przerwał wybuch wielkiego kryzysu ekonomicznego. Jego następstwa miały dla przemysłu piwowarskiego dramatyczne skutki. Wyraźne ożywienie nadeszło dopiero w 1937 r., jednak tuż przed wybuchem wojny liczba czynnych browarów była niemal dwukrotnie mniejsza niż w momencie odzyskania niepodległości, a produkcja ledwie zbliżała się do poziomu powojennego.

\section{Bibliografia}

Balling C.J.N., Anleitung zum Gebrauche des Sacharometers bei der Erzeugung und Prüfung der Bierwürzen zur Bestimmung ihres Extraktgehaltes, sowie zur vergleichsweisen Beurteilung der Qualität der Biere, Prag 1855.

Balling C.J.N., Anleitung zur Vornahme der sacharometrischen Bierprobe, Prag 1855.

Balling C.J.N., Die graphische und tabellarische Auflösung der sacharometrischen Bierprobe, Prag 1848. 
Balling C.J.N., Die sacharometrische Bier- und Branntweinmeischprobe, Praha 1846

Balling C.J.N., Die sacharometrische Bierprobe, Prag 1843.

Barański A., Warsza Z.L., Miary na ziemiach polskich $w$ dobie porozbiorowej, „Pomiary Automatyka Kontrola” 58, 2012, nr 12, s. 1137-1140.

Basařova G., Profesor Pražské techniky Carl Joseph Napoleon Balling (1805-1868), „Kvasný průmysl” 51, 2005, nr 4, s. 130-134.

Bieniaszewski A., Latzke J., Rejestr poboru cyzy z miast Wielkopolski w latach 1462-1465, PH, t. 68,1977 , s. 541-553.

Boczkowski C., Sposoby opodatkowania piwa. Odczyt wypowiedziany na posiedzeniu zjazdu właścicieli browarów, odbytem $w$ Warszawie $w$ dniu 17 i 18 stycznia 1919 roku, Warszawa 1919 (odb. z „Przeglądu Technicznego”).

Boroda K., Geografia gospodarcza Królestwa Polskiego w XVI wieku, Białystok 2016.

Dryja S., Browar parowy w Osieku, Kraków 2017.

Dryja S., Krakowskie miary piwowarskie w XVI wieku, KHKM, t. 59, 2011, nr 1, s. 3-25.

Dryja S., Podatki i opłaty pobierane od piwowarów krakowskich w XVI i pierwszej połowie XVII wieku. Reforma czopowego z czasów panowania Stefana Batorego $i$ jej wptyw na piwowarstwo krakowskie, RDSG, t. 78, 2017, s. $67-94$.

Dryja S., Sławiński S., Mała encyklopedia piwowarska Krakowa i Kazimierza w wieku XVI i pierwszej potowie wieku XVII. Studia $z$ dziejów piwowarstwa Krakowa i Kazimierza z uwzględnieniem problematyki Kleparza i przedmieść, Kraków 2018.

Encyklopedia rolnicza, t. 8: Nawożenie i podlewanie drzew owocowych-Piwowarstwo $i$ stodownictwo, Warszawa 1899.

Głuchowski J., Konsumpcja jako przedmiot opodatkowania: casus akcyza, w: Finanse publiczne i prawo finansowe - realia i perspektywy zmian. Ksiega jubileuszowa dedykowana Profesorowi Eugeniuszowi Ruśkowskiemu, red. L. Etel, M. Tyniewicki, Białystok 2012, s. 413-420.

Kaczkowski J.L., Piwowarstwo, „Gazeta Przemysłowo-Rzemieślnicza” 1875, s. $346,357,363$.

Kochan W., Wyktady na kursach przeszkolenia kontroli skarbowej przy warszawskiej Izbie Skarbowej, Warszawa 1938.

Księga adresowa przemystu, handlu i finansów 1922, pod ogólnym kierownictwem komitetu redakcyjnego przy Ministerstwie Przemystu $i$ Handlu, red. A.R. Sroka, Warszawa 1922.

Landau Z., Tomaszewski J., Zarys historii gospodarczej Polski 1918-1939, wyd. 3, Warszawa 1971.

Latawiec K., Administracja akcyzowa na terenie Królestwa Polskiego w latach 1866-1915, w: Dzieje biurokracji na ziemiach polskich, t. 1, red. A. Górak, I. Łuć, D. Magier, Radzyń Podlaski 2008, s. 261-281.

Lintner C.J., Technologia browarnictwa, oprac. H. Lüers, tłum. P. Wojcieszak, Warszawa 1950. 
„Mały Rocznik Statystyczny” 1932, 1933, 1934, 1935, 1936, 1938.

Manning M.P., Understanding Specific Gravity and Extract, „Brewing Techniques" 1993, kopia w zbiorach autora.

Projekt Biura Kontroli Produkcji i Handlu Piwem, przy Centralnym Zwiqzku Przemystu Piwowarskiego $i$ Stodowniczego w Warszawie, Warszawa 1930.

Projekt ustawy o uregulowaniu stosunków w przemyśle piwowarskim, oprac. Centralny Związek Przemysłu Piwowarskiego i Słodowniczego, Warszawa 1932.

Rady praktyczne dla piwowarów przy stosowaniu nowego sposobu opodatkowania piwa, oprac. K. Kujawski, Warszawa 1902.

„Rocznik Statystyki Rzeczypospolitej Polskiej” 1923 [1924]; 1925/1926 [1927]; 1927; 1928; 1928 [1930].

Spyra A., Browarnictwo Galicji doby autonomicznej, Kraków 1994.

Stacje doświadczalne w Królestwie Polskim, ich zadanie i urzadzenie, Warszawa 1904 (Prace Delegacji Doświadczalnej przy Sekcji Rolnej w Warszawie).

Sterling W., 21/2\% czy 4\%?, druk ulotny, przedr. z „Kuriera Polskiego”, 13 VI 1923.

Szwagrzyk J., Pieniadz na ziemiach polskich $X-X X$ w., Wrocław 1990.

Szymański J., Nauki pomocnicze historii, wyd. 6, Warszawa 2005.

\section{Sławomir Dryja}

Excise duty on beer in the Second Polish Republic against the overall condition of the beer brewing industry

(Summary)

The production of beer, and more broadly the production of alcoholic beverages, has been the source of taxes and other duties and tributes for centuries. The nineteenth century saw the crystallisation of four main methods of collecting excise duty on beer production: it was imposed on the final product (beer for sale), half-product or hopped beer wort (measured after boiling and cooling), raw materials, or the vessels used in beer production. Three different taxation systems were used for beer production in the partitioned Polish lands. In Austria-Hungary, the duty was calculated on the basis of the extract of wort produced, in Russia - the amount of malt used in production, and in Prussia - the final product, namely beer ready for sale. As a result, after Poland regained independence it "inherited" three disparate excise duty systems from the former partitions which unevenly burdened production. The first step taken to remedy the situation was to equalise the three tax rates. As the research has shown, the fiscal authorities successfully fulfilled this challenging task. The introduction of a new consolidated act on excise duty on beer was wearing on due to the devaluation of the Polish mark. The act was eventually passed in 1924 and went into force on 1 January 1925. The government decided to tax the final product, basing the system on German legislation, as 
was also the case with other excised goods. The selected solution was modern and, more importantly, imposed a reasonable burden on beer brewing plants. In the years 1926-1929, beer production in Poland was thriving. The wave of bankruptcies among breweries noticed in the previous years was finally stopped. The upward trend, however, was halted by the great economic crisis. Its echoes reverberated in the beer brewing industry until 1937, when the sector finally became visibly more animated. The unions of brewery owners would take up initiatives aimed at stabilising the situation and providing all production plants equal access to the market.

Sławomir Dryja (ur. 1964) - dr hab., absolwent archeologii na Uniwersytecie Jagiellońskim (1989), gdzie następnie obronił pracę doktorska (1994). Prowadził wiele prac archeologicznych na terenie Krakowa, badał także zamki położone na Jurze Krakowsko-Częstochowskiej (Bobolice, Mirów, Rabsztyn). Specjalizuje się w historii piwowarstwa, ze szczególnym uwzględnieniem Krakowa w XVI i XVII w. Autor kilku książek i kilkunastu artykułów poświęconych tej tematyce. Członek-założyciel Polskiego Stowarzyszenia Piwowarów Domowych. Jeden z animatorów „piwnej rewolucji” na rynku polskim, która doprowadziła do otwarcia wielu nowych browarów i zaowocowała poszerzeniem oferty gatunkowej piw, dostępnych w ogólnej sprzedaży. W 2020 r. uzyskał stopień doktora habilitowanego na podstawie cyklu publikacji dotyczących historii piwowarstwa w Małopolsce, zwłaszcza w Krakowie doby wczesnonowożytnej.

Slawomir Dryja (b. 1964) - dr hab., graduate in archaeology from the Jagiellonian University (1989), where he later defended his doctoral thesis (1994). He has carried out a number of archaeological research projects in Kraków and studied castles in the Kraków-Częstochowa Upland (Bobolice, Mirów, Rabsztyn). He specialises in the history of beer brewing, particularly in Kraków in the sixteenth and the seventeenth century. Author of several books and around a dozen academic papers devoted to the above issue. Founding member of the Polish Association of Home Beer Brewers. One of the prime movers behind the "beer revolution" in the Polish market, which resulted in the foundation of many new breweries and helped broaden the range of beer styles available for general sale. In 2020, he received the title of associate professor for his cycle of publications on the history of beer brewing in Lesser Poland, with particular focus on Kraków in the early modern period.

E-mail: slawomir.dryja@upjp2.edu.pl 